\title{
Persona y fundamento en el Leviatán de Hobbes
}

\author{
José Galimidi \\ Universidad de San Andrés
}

\begin{abstract}
Resumen: La personificación es un dispositivo central en la lógica de la estatalidad desplegada por el Leviatán de Hobbes. De un lado, aparece como concepto indispensable para la comprensión de todas las maneras de encuentro intersubjetivo, tanto cooperativo cuanto agonal, que pueden darse en cualquier ámbito en general, privado o público. Del otro, interviene en la generación del poder de la soberanía absoluta y en la capilaridad de cada instancia en la que esta se hace efectivamente presente en la vida civil, por vía de sus funcionarios, jueces y emisarios. Como todas las figuras conceptuales que ofrece Hobbes, la personificación connota ambigüedades y complejidades que problematizan las estructuras de dominio a las que pretende legitimar. Nuestro trabajo se propone un análisis del potencial de articulación de dicho concepto con miras a la fundamentación hobbesiana de la soberanía y del edificio estatal que esta preside. También entendemos que el dispositivo representacional ofrece un elemento adicional de consistencia para el modelo político de Hobbes, en tanto lo vincula con la dimensión teológica por vía de la representación de la persona divina que corresponde al oficio de soberanía. Palabras clave: Hobbes; persona; representación; soberanía; teología
\end{abstract}

\begin{abstract}
Person and foundation in Hobbes' Leviathan". Personification is a central device in the logic of statehood displayed by Hobbes's Leviathan. On the one hand, it appears as an indispensable concept for understanding all the forms of intersubjective encounter, both cooperative and agonal, that can occur in any sphere, private or public. On the other, it intervenes in the generation of the power of absolute sovereignty and in the capillarity of each instance of the civil life in which it is effectively present, through its officials, judges and emissaries. Like all the conceptual figures offered by Hobbes, personification connotes ambiguities and complexities that problematize the domain structures that it seeks to legitimize. Our work proposes an analysis of the articulation potential of this concept with attention to the Hobbesian foundation of sovereignty and of the state building. We also understand that the representational device offers an additional element of consistency to Hobbes' political model, insofar as it links it to the theological dimension through the representation of the divine person which corresponds to the office of sovereignty
\end{abstract}

Keywords: Hobbes; person; representation; sovereignty; theology 
En diferentes lugares Hobbes da a entender que su Leviatán es el desarrollo de un extenso discurso cognitivo con fines eminentemente prácticos. El autor escribe con la esperanza de que algún gobernante haga suya la voluntad de "convertir esta verdad de especulación en la utilidad de la práctica" . Se busca contrarrestar las miserias de la condición de naturaleza -descritas en el Capítulo 13 como una situación de guerra generalizada- mediante la instauración de un orden artificial que garantice una coexistencia pacífica en lo interior, segura frente a las agresiones exteriores y poseedora de una industria próspera. Aunque Hobbes no es un revolucionario, su escritura alienta un espíritu reformista en tanto propone el acercamiento de la condición de los Estados efectivamente existentes a un punto óptimo de diseño institucional. Esto se lograría mediante el ejercicio pleno de los derechos y responsabilidades de mando y del acatamiento consentido de los ciudadanos. La actualización de este proceso de consolidación del poderío estatal se daría en dos momentos. En primer lugar, los representantes soberanos y los miembros más cercanos del equipo de gobierno deben entender los principios fundantes que Hobbes explica; en segundo lugar, al tiempo que asumen y ejercen la totalidad del poder soberano, los responsables de la república deben procurar la enseñanza de dichos principios a toda la ciudadanía, cuidando que el espacio público no se contamine con opiniones que, con pretensión espuria de cientificidad o santidad, animen a los súbditos a incurrir en actos de rebeldía ${ }^{2}$.

Lo que provee el Leviatán para mejorar sustantivamente las formas de la vida política es una teoría compleja que, sobre la base de una crítica de las tradiciones filosóficas fallidas, habilita un acceso epistémico privilegiado a dos aspectos diferentes de la realidad. Por una parte, permite comprender las causas antropológicas, sociológicas e ideológicas que provocaron los recurrentes fracasos en el ordenamiento de los Estados que registra la historia; por otra, ofrece un modelo óptimo hacia el cual encaminar los esfuerzos de una reforma que, teniendo en cuenta lo anterior, debería ser tanto institucional como cultural. Hobbes intenta un equilibrio que lo mantenga a salvo de los extremos de un utopismo idealista y de un nihilismo desencantado. Su doctrina propone una lógica de lo improbable y todavía no realizado, pero no de lo imposible. Ahora bien, para explicar la naturaleza de ese inmenso hombre artificial que es el Estado hace falta comprender primero al hombre natural. 
Este es tanto la materia de la está hecho el artefacto, como el arquitecto que lo diseña y construye. Esta manera de sintetizar el desarrollo del texto contiene los dos aspectos que mencionábamos. Comprender al hombre natural exige explicar cómo es posible que su estructura motivacional, cognitiva y afectiva, que en ausencia de una autoridad política sana lo insta a tratar a sus semejantes como potenciales enemigos, sea la misma que, en condiciones favorables, podría encontrar los recursos conceptuales y actitudinales que hagan de la vida en común un espacio de cooperación, productividad y confianza. De ahí que Hobbes diga, hacia el final del Capítulo 13, que las mismas pasiones y la misma racionalidad que compone el clima de una guerra de todos contra todos pueden ser reordenadas para superar dicha situación. En otras palabras, se trata de averiguar qué aspectos de la naturaleza humana, tan propensa a la disociación, son los que pueden intervenir en la constitución de una asociación estable y beneficiosa.

En el presente trabajo, nos proponemos estudiar el aporte del concepto de persona a la fundamentación hobbesiana de la teoría del Estado en el Leviatán. Esta tarea involucra atender complejidades de diversa índole. En primer lugar, porque al fundamentar la estructura y la autoridad estatales Hobbes compromete la confluencia de elementos de carácter variado: epistémicos, metafisicos, antropológicos, contextuales, teológicos y retóricos. En segundo lugar, porque el filósofo convoca bajo la figura de la personificación un entramado de nociones como las de autoría, autorización, representación, ministerio, interpretación, reconocimiento, profecía y encarnación. La considerable amplitud del arco hermenéutico da cuenta de la riqueza de la problemática ${ }^{3}$. A los efectos de nuestro interés, podemos esquematizar este campo de lecturas en dos grandes áreas. De un lado están las interpretaciones que, con un tono más o menos crítico, señalan ambigüedades, indeterminaciones o tergiversaciones en los contenidos que la teoría hobbesiana de la personificación asigna a algunas de las nociones que intervienen en ella. Esta línea de comentarios se ocupa de resaltar las dificultades que generan aquellas definiciones y usos postulados por Hobbes al momento de determinar con precisión qué clase de representación ejerce (u obstruye) el soberano, qué tipo de persona es el Estado, qué grado de ficcionalización (en cierto modo, de irrealidad) exige el modelo expuesto

\footnotetext{
3 Para un panorama reciente del estado del arte acerca de la cuestión de la representación en Hobbes, cf., Brito Vieira, M., "Revisiting Hobbes on Representation", en: Hobbes Studies, v. XXXI (2018), pp. 25-29.
} 
en Leviatán para pretender algún tipo de validez, etcétera ${ }^{4}$. Del otro lado, tendriamos lecturas que reivindican la consistencia teórico-práctica del concepto hobbesiano de persona y el beneficio que esto aporta para su función fundante. Se resalta la sinergia analógica entre el ámbito específicamente estatal y los espacios de teatralidad y juridicidad tribunalicia y también la conexión con la trascendencia que, por vía de la secularización, se establece entre el dominio político y la dimensión teológica ${ }^{5}$.

En estas notas, nosotros exploramos una vía más cercana al segundo grupo de interpretaciones. Teniendo en cuenta el significado general del gesto hobbesiano de fundamentación de lo político, señalamos algunas de las dificultades que se asocian con la concepción de la personificación al recorrer las diferentes etapas de la argumentación en la que interviene dicha figura. Partiendo de la configuración motivacional del hombre natural como individuo in abstracto, pasamos por la hipótesis del estado de guerra de todos contra todos $\mathrm{y}$, por vía de la lógica que preside el contrato fundante, reparamos en cómo se establece el poderío del aparato estatal, dirigido por la voluntad soberana y articulado por la delegación de su autoridad. Encontramos que la noción de persona resulta indispensable para la configuración de toda circunstancia de imputación responsable, sea por acción o discurso. También advertimos, como parte de nuestra postura, que los signos de inestabilidad que la condición representativa introduce en la arquitectura estatal no escapan a la percepción del propio Hobbes. Por el contrario: están allí de manera deliberada para resaltar la complejidad del fenómeno estatal en general y la deuda ontológica que el complejo político tiene con la dimensión teológica en particular. La conclusión de nuestro trabajo, que tiene una connotación especulativa, es que la suerte del modelo que el filósofo presenta en su Leviatán depende en gran medida del supuesto subyacente en el texto de una relación de analogía entre el ser humano y el Artífice del Universo, en tanto ambos son seres libres que se representan

\footnotetext{
4 Por ejemplo Pitkin, H., "Hobbes's Concept of Representation”, en: American Political politique chez Hobbes", en: Archives de Philosophie, v. XLVIII (1985), pp. 287-331; Skinner, Q., "Hobbes in Persons, Authors, and Representation", en: Springborg, P. (ed.), The Cambridge Companion to Leviathan, Nueva York: Cambridge University Press, 2007, pp. 157-180.

5 Por ejemplo: Lessay, F., "Hobbes Covenant Theology and its Political Implications", en: Springborg, P. (ed.), The Cambridge Companion to Hobbes's Leviathan, pp. 243-270; Dumouchel, P., "Persona: Reason and Representation in Hobbes's Political Philosophy", en: Substance, v. XXV, 2 (1996), pp. 68-80; Green, M., "Authorization and Political Authority in Hobbes", en: Journal of the History of Philosophy, v. LIII, 1 (2015), pp. 25-47; Dotti, J., "La representación teológico-política en Carl Schmitt”, en: Avatares Filosóficos, v. I (2014), pp. 27- 54; Crignon, P., De l'incarnation a la représentation. L'onthologie politique de Thomas Hobbes, París: Garnier, 2012; Brito Vieira, M., The Elements of Representation in Hobbes, Leiden/Boston: Brill, 2009.
} 
mediante acción y palabra. Por razones de extensión, restringimos nuestras consideraciones a las partes Primera y Segunda del Leviatán, que tematizan la relación de lo humano con lo divino desde la perspectiva de una teología racional y que prescinden de los contenidos revelados en el texto bíblico.

\section{Personas naturales}

El autor de Leviatán confia en que su lector in fabula ejerce una lectura progresivamente integradora. En cada etapa del texto, el filósofo da por hecho que cuenta con el apoyo que le ofrecerá la activación de contenidos anteriormente expuestos. En ocasiones, directamente dice: "como ya expliqué en tal y cual capítulo, etcétera". En todo caso, conviene suponer en la escritura de Hobbes un cierto carácter teoremático, dada su concepción de que la ciencia exige el correcto encadenamiento deductivo de significados y el respeto por definiciones previamente adoptadas ${ }^{6}$. Lo anterior cobra importancia para los contenidos desarrollados en el Capítulo 16 "De las personas, autores y cosas personificadas". Se trata del último capítulo de la Primera Parte, llamada "Del hombre", que recibe y completa una carga teórica que concentra las notas principales de lo que Hobbes mencionará como "las conocidas inclinaciones naturales de la especie humana" ${ }^{7}$. Veremos que persona, autor y todas sus desinencias son conceptos que -a la vez que reúnen las principales notas de la estructura motivacional, cognitiva y comunicativa del modelo hobbesiano de individuo- permiten dar cuenta de las diferentes formas de relación que los hombres pueden establecer con sus semejantes.

Persona natural, define Hobbes, es aquel hombre que realiza acciones y pronuncia palabras cuya propiedad corresponde que le sean atribuidas. El término está tomado del ámbito teatral clásico y, por extensión, del ámbito tribunalicio. Una persona natural es como un actor (en la doble acepción de artista escénico y de agente) que está presentando una postura que él mismo, como autor y en pleno ejercicio de sus facultades intelectuales, ha compuesto o asumido. Tiene todas las afecciones, competencias cognitivas y responsabilidades morales que deben suponerse en alguien que, como se explicó en el Capítulo 14, pretende estar en condiciones adecuadas de entrar como parte en una relación contractual. Mientras los niños y los locos deben ser representados por cuidadores (curators) al no tener pleno uso de razón, la persona natural

\footnotetext{
Hobbes, T., Lev., I, 5, p. 32-33.

7 Ibid., "Revisión y conclusión", p. 489.
} 
es considerada con la "capacidad natural" suficiente para "personificarse" a sí misma y responder por los compromisos que ha suscrito y consentido ${ }^{8}$.

Al considerar las nociones de acción y discurso como constituyentes del concepto de persona natural, el lector está invitado a reponer una síntesis de lo que Hobbes había desarrollado en capítulos anteriores. A los efectos de nuestra argumentación puede valer este breve esquema: cada individuo está inmerso en un horizonte que incluye una amplia diversidad de objetos y situaciones. Algunos de estos impresionan sus sentidos y generan imágenes que a su vez le provocan una sensación corporal placentera y un impulso infinitesimal, al que Hobbes denomina pasión, por acercarse a ellos y tratar de conseguirlos. En tal caso, Hobbes dice que el actor los desea y por eso los llama buenos. Otros, por el contrario, generan imágenes que le causan una sensación displacentera y un impulso a alejarse de ellos. Correlativamente, se dice que les teme y los califica como malos. Se trata de imágenes variadas que pueden remitir a bienes materiales (como alimento, cobijo, instrumentos o territorios) o a configuraciones culturales (como el dinero, el prestigio y las miradas humanas en general, sean aprobatorias, competitivas, amenazantes, despreciativas, etcétera) ${ }^{9}$. Asimismo, pueden referir a situaciones y objetos tanto presentes como ausentes, de existencia efectiva o construida con ecos y retazos de imágenes anteriores. En todo caso, las imágenes que se forman en la intimidad de la mente de una persona por la combinación de los efectos de las cosas y eventos del mundo compiten entre sí con respecto a la intensidad con que la afectan y solicitan. La opinión de bondad o maldad que cada cual se forme de ellas depende de un conjunto de variables muy idiosincráticas y circunstanciales, como su contextura física, su educación y experiencia previa, la opinión y el consejo de gente a quienes la persona respeta, la etapa de la vida en la que se encuentra, su estado actual de salud, de sobriedad o ebriedad, etcétera.

La vida mental y afectiva de cada persona natural está atravesada por una sucesión permanente de opiniones y consideraciones acerca de cómo conseguir lo que desea o evitar lo que teme. Hobbes las llama "discurrires" (discourses). Lo que va imponiendo un cierto orden a esta manera monádica y vertiginosa ${ }^{10}$ de posicionarse frente a las cosas y el mundo es la intensidad predominante de una pasión. Cuando un anhelo o un temor se torna preeminente, termina con el estado de deliberación, disciplina todos los pensamientos y los ordena con

Ibid., I, 16, pp. 111-113.

9 Ibid., Cap. 6.

10 "Thought is quick" (ibid., I, 3, p. 21). 
vistas a diseñar la estrategia que, a juicio de cada uno, mejor permitiría obtener el objeto o la situación que la provocó. La meta deseada con persistencia impide que los pensamientos se dispersen y los "reconduce" mediante una decisión hacia el camino correcto ("they are quickly again reduced into their way"). Un acto voluntario es la expresión puntual de la manera en que un hombre, en un lugar y un momento determinados, coordinó sus capacidades perceptivas y sus recursos con el propósito de evitar algo que le parecía malo o de obtener algo que le parecía bueno, en sí mismo o como medio para otra cosa. Es una ilustración concretamente situada de su esquema de preferencias, de su grado de prudencia o astucia, de la intensidad con la que desea o teme, de su momento existencial, etcétera. Un acto voluntario es una muestra episódica de la manera en la que un actor decidió personificarse a sí mismo, reduciendo una multiplicidad interior, invisible y mental a cierta unidad exterior, visible y fisica.

En cuanto a lo que dice una persona natural, la composición es equivalente a la de sus actos voluntarios. Para Hobbes, el lenguaje es una invención poderosísima porque permite que una persona conserve registro mediante marcas sonoras o gráficas -las palabras- de las experiencias y objetos que son relevantes para su existencia. Asimismo, puede comunicar a otros semejantes parte de lo que puebla su mundo interior. Vivencias íntimas como los afectos, deseos, temores y saberes, se expresan y hacen públicos en forma de propósitos declarados, argumentos, opiniones, órdenes, consejos, pedidos, juegos poéticos, etcétera. El lenguaje es la condición de posibilidad para una convivencia colaborativa y constructiva porque es una manera específica de actuar voluntariamente, mediante la apelación a la voluntad y la comprensión del otro ${ }^{11}$. Sin embargo, igual que las acciones físicas, las palabras que un actor pronuncia o escribe para comunicar un estado mental o emocional también son resultado de la decisión que sigue a una deliberación. Obedecen, como todo acto voluntario, a la intención de cumplir un propósito, razón por la cual también tienen que pasar por un proceso de selección y de ordenamiento estratégico. A tal punto que la primera instancia de control interior que se autoimpone el hablante consiste en decidir si lo que va a ejercer es un uso o un abuso del lenguaje, es decir si va a ser sincero y veraz o si va a mentir. Tomada esta primera decisión, lo que sigue por medio del acto de habla, como en toda acción voluntaria en general, es una cierta reducción de lo múltiple interior (sentido, pensado e invisible) a algo que es uno, exterior y perceptible ${ }^{12}$.

11 Ibid., I, 4, p. 24.

${ }^{12}$ Ibid., I, 4, pp. 25-26.

ARETÉ Revista de Filosofía, v. XXXII, 2, 2020 / ISSN 1016-913X 
Para completar este esquema resta mencionar la cuestión del poder. Hobbes define el poder de una persona como su disponibilidad actual de recursos para obtener cosas que en el presente le parecen buenas, es decir, como su capacidad para conseguir lo deseado y eludir lo temido. Aquí el repertorio de recursos á considerando por Hobbes es tan amplio como lo es la variedad de situaciones y objetos que pueden causar deseo o temor: aptitudes naturales; aptitudes adquiridas por la práctica y el aprendizaje; bienes externos como riquezas, linaje, amigos, aliados, prestigio, privilegios, cargos públicos, golpes de fortuna, etcétera. Dicho en términos de su teoría, se trata de poderes que pueden ser naturales o instrumentales ${ }^{13}$. Las características del deseo humano son muy peculiares porque, según su concepción antropológica, cuando los hombres desean algo concreto no se conforman con intentar una vez su obtención, sino que necesitan tener la certeza de que podrán conservarlo o volver a acceder al consumo de algo similar cada vez que lo deseen. En cada momento determinado los actores necesitan disponer de poder en dos dimensiones: una inmediata, para tener éxito en lo que decidieron intenta; otra mediata, para saber que podrán volver a intentar su obtención o que garantizarán su conservación en el futuro. Esto es universal porque nadie tiene nunca garantías de que en el futuro tendrá poder suficiente para obtener y conservar lo que en un momento determinado deseará o necesitar. Eso es especialmente así teniendo en cuenta que, en la concepción de Hobbes, los hombres aman el dominio sobre sus semejantes. Esta autopercepción de carencia insanable afecta a toda persona viva y consciente. La condición deseante y, en un punto, necesariamente agonal del actor, tensa su mente y torna su existencia una búsqueda incesante de poder que solo cesa con la muerte ${ }^{14}$. Bajo esta perspectiva, las palabras y los actos concretos de cada persona natural pueden verse como una manera de expresar su permanente trajinar entre el deseo, el temor y la necesidad de poder.

Ahora bien, si el afán de poder fuera la única o principal característica relevante de la naturaleza humana, el problema político de la coordinación de las voluntades sería insoluble. Como contracara de la tendencia a la búsqueda de poder sobre los demás, Hobbes postula otra dinámica básica del comportamiento interpersonal, que en el Capítulo 11 del Leviatán recibe el nombre de "maneras". Este concepto se refiere a aquellas cualidades de la especie humana que interesan al problema de vivir en común, en paz y unidad. Según el filósofo, junto con la intención de dominio coexisten pasiones como el gusto

${ }^{13}$ Ibid., I, 10, p. 62.

${ }^{14}$ Ibid., I, 11, pp. 70-72.

ARETÉ Revista de Filosofía, v. XXXII, 2, 2020 / ISSN 1016-913X 
por la tranquilidad, el deleite sensual, el estudio, la labor productiva, etcétera. Estos motores de la voluntad, sumados al temor a la muerte violenta y a las lesiones, predisponen a obedecer a un poder aceptado por muchos porque "tales deseos llevan a un hombre a abandonar la protección que podría esperar de su propio esfuerzo y trabajo" ${ }^{\text {. }}$.

Se ve, por lo expuesto, que persona natural es un concepto esencialmente relacional. Por eso la definición hobbesiana de persona debe incluir la mención de un testigo o interlocutor que atribuye autoría y responsabilidad: "una persona es aquel cuyas palabras o acciones son consideradas o bien como suyas, etcétera" ${ }^{\prime 16}$. La figura del actor que se personifica a sí mismo es esencialmente la elaboración de una interioridad que va apareciendo ante otro. En este aparecer de Pedro hablando o actuando ante Juana se pone en acto una cierta facultad hermenéutica ${ }^{17}$. Por un lado, Pedro sabe o intuye que su acción y sus dichos, que para él tienen una meta determinada, pueden ser leídos por Juana o bien como una acción significativa o bien, por el contrario, como inarticulados y sin propósito. Solo una vez que Pedro se reconoce considerado por Juana como actor responsable y a cargo de sí mismo, se abre la posibilidad de que sus acciones y dichos sean, o no, correctamente decodificados de acuerdo con su intención original. De manera correlativa, la otra característica existencial que Hobbes nos invita a considerar cuando propone el concepto de persona natural consiste en que, para que Juana pueda atribuir a Pedro la condición de autor, es indispensable que ella misma tenga minimas competencias interpretativas. Es necesario que a partir de la percepción de una presencia corporal que emite movimientos y palabras, estas le permitan conjeturar una compleja riqueza interior de pasiones, pensamientos y propósitos. Ser la contraparte competente de una persona natural que actúa y se representa a sí misma implica involucrarse en un proceso hermenéutico que también es basal porque consuma la dualidad esencial ser-aparecer. Enfrentada a otro cuerpo humano y a partir de sus percepciones y deducciones, Juana tiene que decidir, en primer lugar,

\footnotetext{
15 Ibid., p. 71. Para un estudio sobre el dualismo radical de la condición natural del hombre de Hobbes, tan propenso a la enemistad cuanto a la cooperación pacífica, $c f$. Hermosa Andújar, A., "Sociedad natural y Estado en Hobbes", en: Fragmentos de Filosofia, v. VII (2009), pp. 49-85.

16 Ibid., I, 16, p. 111.

17 Nos referimos aquí a la capacidad hermenéutica en un sentido lato, significando la facultad de conjeturar intenciones mentadas por un conjunto de indicios aparentes. Conscientes, sin embargo, de la relevancia del término en la historia de la filosofia, pensamos que la centralidad del momento interpretativo que postula la eidética hobbesiana puede considerarse con provecho desde una perspectiva contemporánea como la de Paul Ricoeur (cf., Ricoeur, P., Hermenéutica y acción, Buenos Aires: Prometeo libros, 2008).
} 
si este pertenece a un autor pleno o a un niño o a un loco. Si toma a Pedro como persona natural, como owner con dominio sobre sus dichos y actos, proyecta sobre él todo lo que sabe estructuralmente de sí misma ${ }^{18}$. Solo recién a partir de esta primera decisión interpretativa, se pondrá a leer sus sonidos y movimientos físicos como manifestación externa y significativa de una vasta complejidad interna, a la que no puede acceder de manera directa, tratando de servir a sus propios gustos, propósitos y necesidades.

La condición autoral de las personas naturales es la clave teórica de comprensión para todo encuentro presencial entre dos seres humanos con pleno dominio de sí mismos. Lo notable es que esto vale tanto para la cooperación cuanto para la enemistad, que son los dos modos excluyentes en los que se puede configurar cualquier espacio de interacción ${ }^{19}$. En cuanto a la cooperación -o al menos, en cuanto a la abstención de agresión- Hobbes sostiene que cualquier persona en condición autoral (un adulto en pleno ejercicio de sus facultades mentales y con imputabilidad moral) tiene por lo menos alguna intuición elemental del espíritu de las leyes de naturaleza. Sabe que, en la medida de lo posible, debería esforzarse por tratar al otro con el mismo respeto con el que querría verse tratado ${ }^{20}$. Su mundo anímico es siempre un foro interno de modo que, si dos autores coexisten de modo no violento, es porque ambos están suponiendo implícitamente que la respectiva contraparte ha decidido hacer valer, en el foro externo, algo de lo que manda la ley natural. Por consiguiente, se abstienen de ejercer el derecho que les otorga la Naturaleza sobre el cuerpo y la vida del otro, se disponen a cumplir con lo prometido, aceptan buscar un árbitro que salde sus diferendos, etcétera. Dicho de otro modo, disponernos a interactuar de manera no agresiva con alguien en particular supone haber decidido que los signos que tomamos a partir de su presencia y actitud lo muestran como una persona suficientemente confiable que, al menos por el momento, está dispuesta a moderar su tendencia radical a incrementar su poderío a costa de nosotros y a darle libre curso a sus manners.

En cuanto a la enemistad, sucede algo análogo, pero inverso. Veamos, por ejemplo, la segunda causa natural de guerra tal como se la explica en el Capítulo 13. Pedro se encuentra en condición extraestatal de naturaleza y se

\footnotetext{
${ }^{18}$ Hobbes, T., Lev., Introd., p.10. Para una interpretación del concepto hobbesiano de persona como artificio/máscara que esconde y disimula el desenfreno pasional que anima la vida interior de todo individuo, loco o cuerdo, $c f$. Rilla, R., El Leviatán como prosopopeya: hacia una nueva teoría del conflicto en Hobbes, Buenos Aires: TeseoPress, 2019, Capitulo 3, "Personas", pp. 175-250.

${ }^{19}$ Hobbes, T., Lev., I, 13, pp. 88-89.

${ }^{20}$ Ibid., I, 15, pp. 109-110.
} 
considera en una relativa situación de ventaja táctica respecto de sus vecinos Juana y Pablo. Para atacarlos por prevención y desconfianza, Pedro tiene que haber llegado previamente a la conclusión de que estos representan un peligro potencial para su integridad porque, en ausencia de datos tranquilizadores, les está adjudicando un comportamiento estratégico que comprueba en sí mismo en el presente estado de alerta extrema. Golpea primero porque se anticipa a lo que sabe que él mismo trataría de hacer si estuviese en el lugar de sus vecinos ${ }^{21}$. El punto queda todavía más claro si consideramos la tercera causa natural de guerra $^{22}$. Cada actor, postula Hobbes, quiere que los demás expresen, en sus actos y dichos, una valoración de su persona que no debería ser inferior a la que él tiene de sí mismo. Lo quiere porque es propio de la naturaleza humana disfrutar las manifestaciones de valia por parte de otros y porque la opinión positiva de los demás sobre el propio poder también es un cierto poder instrumental $^{23}$. Por consiguiente, que Pedro ataque a Pablo porque este lo insulta, ofende o dirige una mirada despreciativa, supone que primero tiene que haber dado por sentado que este último tiene pleno dominio autoral sobre sus gestos y dichos. Esto implica que lo que Pablo dice y hace representa en público, ante, digamos, Juana, un estado interno de conciencia determinado que, a la sazón, Pedro odia o cuya expresión lo perjudica. El resultado óptimo del ataque por vanagloria de Pedro a Pablo sería que Juana, la testigo, lo respete, y que Pablo, el ofensor, cambie internamente su opinión sobre él. El mínimo deseable sería que, si es que sigue despreciándolo en su fuero interno, al menos no lo manifieste ni con palabras ni con actitudes.

En resumen, nos interesa señalar que lo que "ve" el testigo o interlocutor en cada aparición de una persona natural es una alguna forma de ordenamiento que reconduce su agitación interior a un acto o dicho puntual externo. La interacción entre dos personas naturales consiste en que cada uno sabe que el otro está mostrando solo una parte de sus pasiones y pensamientos y que a cada momento tiene que tomar simultáneamente dos tipos de decisiones. Por un lado, qué decir y qué hacer; por otro, decodificar los actos y los dichos de quien tiene enfrente. La conjetura sobre el semejante se construye con lo que se sabe o se intuye de uno mismo: que uno siempre está animado por una búsqueda incesante de poder, que también necesita poder colaborar, que puede querer mentir, disimular, engañar, etcétera. Además, uno siente que todas estas

21 Ibid., pp. 87-8 8 .

22 Ibid.

${ }^{23}$ Ibid., I, 10, p. 62. 
opciones están habilitadas en ambos por el derecho natural. Sabe que tiene que tomar una primera decisión dramática, que es la de considerar o no al otro como un enemigo. Al elaborar el concepto de persona natural Hobbes está aludiendo a las competencias interpretativas necesarias para que alguien sea considerado como tal por su semejante. Persona natural o autor, proponemos entonces, es el concepto que le permite a Hobbes analizar la microfísica ${ }^{24}$ de la aparición de un ser humano adulto frente a otro y la consiguiente adjudicación recíproca de humanidad responsable, en tanto reconocimiento de la capacidad voluntaria para decidir alguna forma de mediación entre una interioridad, múltiple y secreta, y su manifestación activa, única y pública.

\section{Personas artificiales}

Ahora bien, dado que el asunto del Leviatán es lo político y que lo que interesa es teorizar la dinámica de los hombres en multitud, hace falta todavía potenciar la capacidad de articulación del concepto de la persona natural que se representa a sí misma ante otra. Con este propósito, Hobbes ofrece el concepto de persona artificial o representante. La definición general establece que la personalidad artificial es el modo en que alguien está cuando emite acciones y palabras que deben ser atribuidas a otro. La persona artificial personifica o representa a ese otro porque porta su persona, del mismo modo que los actores clásicos se cubrían en escena con las máscaras y trajes que caracterizaban al personaje de la pieza. Esta situación de personificación supone una cierta puntualización acerca de cuáles son los asuntos en los que la representación es lícita, es decir, se debe especificar cuál es la incumbencia y el alcance del poder otorgado y también se debe extender algún modo de acreditación, formal o implícita, como constancia para con los terceros que hayan de interactuar con el representante. Dado que Hobbes entiende que un autor es alguien con derecho de acción y de palabra, representar a un autor es convertirse, por cierto tiempo, en actor, fungiendo por comisión, con la autorización (by Authority) que ha otorgado el poseedor originario de tal derecho. Es momento de tener a la vista, in extenso, los principales párrafos de referencia: "una persona es aquel cuyas palabras o acciones son consideradas o bien como suyas [as his own], o bien como representando las palabras o acciones de otro hombre, o de otra cosa,

\footnotetext{
${ }^{24}$ La referencia contemporánea para el análisis de la dinámica de las interacciones interpersonales en términos de poder, es, obviamente, Michael Foucault ( $c f$. Foucault, M., Microfísica del poder, Madrid: Las Ediciones de La Piqueta, 1979).
} 
a los cuales se le atribuyan, ya sea verdaderamente, o por ficción. Cuando se las considera como suyas, entonces se lo llama persona natural. Y cuando se las considera como representando las palabras y acciones de otro, entonces es una persona ficticia [Feigned] o artificial... una persona es lo mismo que un actor, tanto en escena cuanto en la conversación cotidiana; y personificar es actuar o representar, o bien a sí mismo, o bien a un otro. Y el que actúa por otro, se dice que porta su persona, o que actúa en su nombre... y se lo llama diversamente, según las diversas ocasiones: representante, representativo, lugarteniente, vicario, abogado, procurador, actor, y así. De las personas artificiales, hay algunas cuyas palabras y acciones pertenecen a aquellos a quienes representan. Y entonces, la persona es el actor, y el que posee sus palabras y acciones [he that owneth his words and actions], es el autor... por autoridad [Authority] siempre se entiende derecho de ejecutar una acción, y hecho por autoridad, significa hecho por comisión o licencia de aquel a quien asiste tal derecho" ${ }^{\text {"25 }}$.

La matriz que propone el concepto de persona artificial es potenciadora de la célula elemental persona natural porque permite que el número de subjetividades a ser articuladas pase de dos a tres. Esquemáticamente se trata ahora de: un autor o titular del derecho de autoría, A; de un representante o actor, $\mathrm{B}$; $\mathrm{y}$ de un indeterminado $\mathrm{C}$ que, dependiendo del tipo de encargo, puede ser público espectador, contraparte en un contrato, ciudadano, reo en un juicio penal, magistrado, cliente, soberano, diplomático extranjero, etcétera. A efectos de exposición, se puede especificar el esquema en dos subgrupos según qué tipo de autor sea A. En el primer subgrupo, el autor A al que representa la persona artificial B no es una persona natural con pleno ejercicio de sus facultades intelectuales, estratégicas, emocionales o ejecutivas. Para actualizar alguno de los derechos que la asisten, se le adjudica la autoría de acciones o palabras, efectivamente emitidas por B que, por diferentes razones, A no pudo haber comisionado ni producido en la realidad acaecida, sino solo en una ficción operativamente necesaria. En este primer subgrupo se pueden incluir los personajes de una pieza teatral, los ídolos, las construcciones públicas como puentes y los diversos tipos de asociación de hombres a los que Hobbes llama sistemas $^{26}$, como los infantes, locos, etcétera. La representación tutorial de

\footnotetext{
${ }^{25}$ Hobbes, T., Lev., I, 16, pp. 111-112. Las cursivas son de Hobbes.

${ }^{26}$ Hobbes, T., Lev., I, 22, p. 155. Respecto de la muy comentada controversia entre Skinner y Runciman acerca de qué clase de persona sea para Hobbes el Estado, nos parece relevante la revisión que recientemente hace Paul Sagar. Este autor tercia diciendo que, si bien no hay tal cosa como "personas ficticias" (Skinner), tampoco es tan clara la categorización de la república como persona artificial (Runciman). Según Sagar, además de los dos tipos de personas, las artificiales
} 
alguien o algo solo puede ser validada por la autoridad de un Estado que, a la vez que protege la actualización de los derechos de autoría de A y certifica las credenciales que exhibe $\mathrm{B}$, también garantiza a la contraparte $\mathrm{C}$, la condición de aquellos como sujetos jurídicos responsables.

En el segundo subgrupo, que es el que nos conviene considerar con mayor atención, el autor A sí es una persona natural en plena posesión de sus facultades mentales, con su mundo interior poblado de intereses, apetitos y aversiones, con su repertorio de poderes naturales e instrumentales disponibles, etcétera. Uno de sus tantos actos voluntarios consistió, precisamente, en comisionar a otro con la propia presencia, accionar y decir. A tal efecto tuvo que precisar qué derechos delegar, con qué propósitos y límites y con qué tipo de credenciales. Básicamente tuvo que decidirse también a confiar en los buenos oficios y en la buena fe de su representante. El autor A asumió el riesgo de dar por sentado que su comisionado B tiene la aptitud para ser un intérprete competente de sus encargos y un ejecutor leal. Los motivos que lo llevaron a esta combinación de decisiones pueden ser muy variados. A, por ejemplo, carece de cierto expertice que B sí tiene; o debe comisionar algunas tareas porque tiene otras ocupaciones que lo reclaman de manera inmediata; o necesita "estar" en más de un sitio al mismo tiempo; o prefiere no someter su prestigio al desgaste de la aparición física permanente, etcétera. Por último, y no menos importante, A también está confiando en que $\mathrm{C}$, que es el que va a tratar efectivamente con su comisionado B, será capaz de leer adecuadamente los términos de la credencial (formal o implícita) que se le exhibe y en que sabrá atribuir los actos y palabras del comisionado a su mandante, es decir, que sabrá tratarlo como una persona artificial. En cualquier caso, debe quedarnos clara la obviedad de que este confiarse de A a un otro B, y todavía a la correcta percepción de un $\mathrm{C}$, es, en sí mismo, un acto voluntario que obedece a la admisión de alguna necesidad o deseo. Mediante el acto de delegar la propia presencia, está reconociendo

y las naturales, habría dos formas de ejercer la representación: la real, de personas naturales y responsables, y la ficcional, de cosas y agrupaciones de gente que no pueden tener una postura única o genuinamente propia. La lectura que propone Sagar es que la república hobbesiana es algo único en su tipo (persona artificial representada en forma ficcional) y por eso relativamente indeterminado, que tiene un poco de máquina y otro poco de personalidad. De un lado, puede ser manejada por un conductor soberano; por el otro, es capaz de sostener compromisos jurídicos en el tiempo más allá del cambio generacional de individuos ( $c f$. , Sagar, P., "What is the Leviathan?", en: Hobbes Studies, v. XXXI (2018), pp. 75 -92; Skinner, Q., "Hobbes and the Purely Artificial Person of the State", en: Journal of Political Philosophy, v. VII (1999), pp. 1-29; y Runciman, D., "What Kind of Person is Hobbes's State? A Reply to Skinner", en: Journal of Political Philosophy, v. VIII (2000), pp. 268-278). 
implícitamente que esta es la mejor manera de satisfacerlo por el momento. Como todo ser humano en general, el mandante A, al autorizar a un actor B, se está mostrando en una condición relativamente potente y carente a la vez.

Si viramos la atención sobre el representante B, las consideraciones son correlativas con las precedentes. B no es en modo alguno una marioneta sin pensamiento ni voluntad. Para estar en condiciones de portar con eficacia la persona de A, debe, antes que nada, poder cargar adecuadamente con su propia combinación de aptitudes, intereses y poderes. En primer lugar, B opta por dar por cierto que A es dueño legitimo de las acciones y palabras que le propone representar. Al aceptar el encargo está decidiendo, por razones que en principio solo él conoce, que comprometer su persona natural, su capacidad y su buen nombre en el empeño acordado es bueno no solo para A, sino también y principalmente para sí mismo. Representar, igual que autorizar, es una acción voluntaria y tiene aspectos que requieren de una competencia muy fina. El actor representante está, por así decirlo, en tiempo real frente a la situación concreta para la cual el autor solo le dio (solo le pudo dar) indicaciones con un cierto grado de indeterminación ${ }^{27}$. Tiene que ser un buen lector del espíritu de la tarea encomendada y tiene también que cuidar, en la medida de lo posible, la limpieza del mensaje que está emitiendo con su accionar para dejar en claro cuándo es que habla y actúa como representante y cuándo como la persona natural que nunca deja de ser. Su accionar y su discurso, a la vez que vienen determinados por la naturaleza del encargo, también exigen un cierto grado de prudencia y de libertad creativas. En términos de Kant, el representante $\mathrm{B}$ debe hacer un uso privado de su razón. Sin embargo, representación no es identificación masiva y es aceptable que los intereses y sentimientos profundos de B no sean idénticos a los de A. La lógica de la situación implica que la aceptación del encargo por parte de B es una manera, entre tantas otras, de hacer efectiva su propia pugna, existencial y permanente por el prestigio, poder o dinero. Aunque sea obvio, no está de más reparar en que B es el autor efectivo

\footnotetext{
${ }^{27}$ Puede inducir a error la imagen etimológica que propone Hobbes: es verdad que cuando B es un actor de teatro se debe ceñir a recitar un texto, y a remedar acciones preestablecidas por el libreto, y que, por tanto, su margen sustantivo de libertad es, se diría, bastante limitado. Sin embargo, aun en el caso de un actor teatral hay mucho para observar. En primer lugar, los hay buenos y malos, profesionales y vocacionales. Un actor pésimo provoca vergüenza ajena, y no permite que el espectador entre en el juego de la ficción. No representa a su personaje, no lo hace presente, sino que, por el contrario, con su impericia interpretativa desnuda la ficción y la desbarata. Es decir, aun el actor que dice un texto con acciones preestablecidas tiene que agregar algo sustantivamente propio, que es, precisamente, su interpretación, para que la representación teatral acaezca en plenitud.
} 
de las palabras y actos que habrán de ser atribuidos a su representado A. En tal sentido, no corresponde descartar la eventualidad de que B pueda llegar a portarse como desleal, inepto, o ambas cosas a la vez: ya sea porque aceptó la comisión a sabiendas de que no tiene el carácter y la pericia que exigiria la situación; ya porque, una vez en funciones, prefiere adelantar sus intereses privados por encima de los comprometidos con su mandante. B es un hombre, no una máquina ni un santo.

Finalmente, está el interlocutor o contraparte C. La persona natural ante la cual B representa a A es, podría decirse, el punto focal hacia el que confluye la serie. Su papel no es en absoluto pasivo porque es su voluntad inteligente la que decide en última instancia la convalidación o impugnación de todo el proceso. En su situación, C tiene muchos pormenores para evaluar y actuar en consecuencia. A saber: debe aceptar o rechazar las cartas credenciales de $\mathrm{B}$, juzgar si este está siendo leal al encargo de su mandante, y ponderar si el hecho de aceptar el trato con A por interpósito B será o no una manera eficaz de servir a sus propias necesidades y propósitos. Ante $\mathrm{C}$ se consuma el proceso de la representación. Por tal razón, esta última persona debe contar con la disposición adecuada y con la pericia interpretativa suficiente como para resignificar, a partir de un suceso fisico concreto, una cadena de personificaciones y autorias superpuestas. No solamente tiene que poder conjeturar que ante sí tiene a una persona natural (B) con una interioridad compleja que se manifiesta ante él en la particularidad determinada de sucesos físicos, sino también tiene que poder jugar el juego de "ver", en algunos de sus dichos y acciones, las intenciones de un otro representado y conjeturar, como escribe el filósofo, su "scope and purpose". En otras palabras, para que se realice en plenitud el dispositivo de personificación artificial, el interlocutor $\mathrm{C}$ debe ser consciente de que el representante $\mathrm{B}$ es y no es el autor de los dichos y acciones que está presenciando y que, eventualmente, han de atribuirse a su representado A.

Adelantemos, para completar este apartado, la siguiente consideración. $\mathrm{El}$ concepto de persona natural que ofrece Hobbes puede verse como la expresión de un principio ordenador que, mediante la determinación voluntaria de un propósito, propicia la transformación de una multiplicidad interior de pasiones e imágenes en una sucesión de acciones concretas. La categoría de persona artificial agrega a este complejo teórico dos elementos particularmente relevantes. En primer lugar, asocia al dispositivo de la personificación natural la capacidad hermenéutica y activa de representar a otro. En segundo lugar, permite concebir la superposición ordenada de diversas voluntades en una 
aparición única, ya como representación triádica elemental (A representado por $\mathrm{B}$ ante $\mathrm{C}$ ), ya como representación de voluntades agrupadas (el sistema de voluntades particulares A, A', A“... representado por B ante C, que también puede ser un particular, un grupo indeterminado, u otro sistema con su propio representante). Hobbes hará pleno uso de la función ordenadora y unificadora del dispositivo representacional cuando diga que lo que hace real la unidad de una multitud de personas naturales que integran un sistema político no es otra cosa que la unidad de su representante ${ }^{28}$. Con las diferencias del caso en cuanto a los contenidos unificados (pasiones e imágenes para las personas naturales, voluntades ya individualmente determinadas para las personas artificiales), el criterio es el mismo: Hobbes, con realización por vía de la personificación, está significando reducción de una multiplicidad dispersa a la unidad efectiva y eficaz de propósito y acción.

\section{El poder soberano y las propiedades de la persona}

No es necesario extendernos aquí sobre el detalle de la aritmética conceptual mediante la que nuestro filósofo da cuenta de la institución de la república. El lance es bien conocido. En condición extraestatal, la vida de una multitud de hombres que habitan un territorio es miserable. Para terminar con tal situación es necesario que erijan un poder común con capacidad suficiente de legislación, judicatura, administración, instrucción, policía, milicia, y con condiciones de legitimidad claras y consentidas. Una estructura tal solo se puede concebir como resultante de un proceso de intercambio de compromisos recíprocos, en el que cada uno propone una misma fórmula a cada otro. Esta podría ponerse así: "me comprometo contigo, con la condición de que tú te comprometas conmigo de manera semejante, a asumir como propias las palabras y actos del individuo o grupo de individuos que resulte elegido por mayoría en la presente asamblea, a poner a su disposición mis recursos y a aceptar como justo y conveniente lo que él o ellos decidan al fin de cuidar de nuestra paz interior y defensa común" ${ }^{29}$. Con este proceso, la multitud queda unificada en una asociación o sistema, que Hobbes define como república (Commonwealth), y la persona o grupo, designados por mayoria para su gobierno, son sus representantes soberanos. Representantes, porque deben ser considerados como actores autorizados por cada uno de los miembros para portar la persona del cuerpo político al que

\footnotetext{
${ }^{28}$ Hobbes, T., Lev., I, 16, p. 114 y I, 17, p. 120.

29 Ibid., I, Cap. 17.
} 
todos han decidido pertenecer; soberanos, porque detentan con legitimidad el máximo poder instrumental que puede ser concebido, para ejercerlo de una manera que no rinde cuentas ante ningún tribunal institucional humano ${ }^{30}$. Según la visión contractualista de Hobbes, este acto fundante de comisión establece que el propósito del poder acumulado en manos del representante es el de proveer a una situación perdurable de seguridad y dignidad, con cierto confort y desarrollo productivo, paz en el territorio y protección contra atacantes de otras regiones. Dejemos de lado la enumeración de los contenidos que la lógica hobbesiana deriva de la fórmula generadora, es decir, los alcances del derecho de soberanía absoluta, las libertades y responsabilidades de los súbditos y las especificidades del officium gubernativo. Nos interesa comentar algunos aspectos problemáticos de la lógica del proceso mismo de constitución de la autoridad política y relacionarlos con la cuestión de la propiedad privada.

Es un tópico muy comentado el hecho de que la doctrina de Hobbes -a diferencia, por ejemplo, de la de Locke- no reconoce la propiedad privada de bienes como un derecho de las personas particulares que sea previo e independiente respecto de la instauración de la sociedad política. Hobbes lo postula repetidas veces. Leemos, por ejemplo, en el Capitulo 15: "la justicia y la propiedad (Propriety) comienzan con la constitución de la república”, ${ }^{31}$. Las líneas generales del argumento que sostiene esta afirmación, que es nave insignia de toda la filosofia política hobbesiana, se pueden resumir de la siguiente manera. En la condición de naturaleza, cada hombre tiene un derecho natural a todas las cosas, lo cual incluye el cuerpo y la vida misma de sus semejantes. Esta universal disponibilidad de todos los hombres sobre todas las cosas, que legitima la puja personal por la autopreservación, hace también que la condición natural sea, si se quiere, doblemente peligrosa, porque a la vez que de hecho y por motivos estratégicos cada uno tiende a confiar solo en su propio criterio para decidirse a intentar el manejo discrecional de los objetos y cuerpos que lo rodean, cuenta además con el respaldo de un cierto derecho que lo habilita en conciencia a sostener esta actitud. En la lucha que actualiza la enemistad

30 Ibid., II, 17, p. 137. Sobre este punto, Skinner argumenta que Hobbes ejerce una estratagema retórica, pues toma el lenguaje de los radicals parlamentaristas, que reivindicaban, precisamente, la función insuprimible de la representación popular como freno institucional a las pretensiones tiránicas de la monarquia, y la neutraliza, al conceptualizarla como delegación irrevocable ( $c f$. Skinner, Q., "Hobbes on Persons, Authors, and Representatives", en: Springborg, P. (ed.), The Cambridge Companion to Hobbes's Leviathan, pp. 159-160). En un sentido similar la crítica de Pitkin, H., "Hobbes's Concept of Representation", en: American Political Science Review, v. LVIII, 2 (1964), p. 331).

${ }^{31}$ Hobbes, T., Lev., I, 15, p. 100. 
universal de la condición natural, cada uno está pugnando por preservar no solamente su integridad biopsicológica, sino también y especialmente su dignidad como sujeto moral. Dado que ser propietario de algo significa que se tiene el derecho de disponer de un bien que nadie más puede tomar de manera válida, la acción soberana que establece los términos de la propiedad privada implica un giro radical respecto de la condición natural. A la vez que obliga a una renuncia general de todos a todas las cosas, habilita, de manera positivamente legal, un acceso particular privilegiado de cada uno a determinados bienes, comenzando por las vidas y cuerpos respectivos. Hobbes da a entender que se trata de una compensación: se abandona un derecho formalmente universal y se obtiene a cambio la posibilidad concreta de adquirir derechos exclusivos sobre bienes específicos. La instancia que "hace buena" la propiedad de cada uno sobre su cuerpo y sus cosas es, precisamente, el poder soberano común que, con su capacidad coercitiva, desactiva el temor (muy sensato en condición natural) a ser el primero en cumplir un pacto de intercambio y luego verse perjudicado por el incumplimiento de la contraparte. Uno de los poderes anexos a la soberanía, entonces, es el de prescribir normas claras que permitan a cada uno saber qué bienes puede disfrutar sin ser molestado por sus conciudadanos: "las normas de la propiedad (de Meum y Tuum), y de lo bueno, malo, legal e ilegal en las acciones de los súbditos, son las leyes civiles...”32.

En vista de lo que acabamos de resumir, en condición de naturaleza y por la ausencia de un poder soberano, no hay propiedad: "there is no Own" Si volvemos con atención a los pasajes centrales del Capítulo 16 ya citados, nos encontramos con una disonancia porque al plantear la naturaleza de la relación que existe entre autores y actores mencionada en nuestro apartado anterior, notamos que Hobbes dice que: "UNA PERSONA es aquel cuyas palabras o acciones son consideradas o bien como suyas (as his own), o como representando las palabras o acciones de otro hombre, o de otra cosa, a los cuales se le atribuyan, ya sea verdaderamente, o por ficción... de las personas artificiales, algunas tienen sus palabras poseídas [owned] por aquellos a quienes representan. Y entonces esta persona es el actor, y el que posee [owneth] sus palabras y acciones es el AUTOR. En cuyo caso el actor actúa por autoridad. Pues aquel que hablando de bienes y posesiones se llama Poseedor [Owner], en latín Dominus... hablando de acciones se llama Autor. Y así como el derecho

${ }^{32}$ Ibid., II, 18, p. 125. Paréntesis de Hobbes.

33 Ibid., I, 15, p. 101. 
de posesión se llama dominio, el derecho de realizar una acción se llama AUTORIDAD..." ${ }^{34}$.

Si reteniendo el detalle de este párrafo reparamos ahora en que el pacto fundacional relatado en el Capítulo 17 consiste en un intercambio reciproco de promesas de autorización en favor de un hombre o asamblea de hombres, nos encontramos con esta tensión: en la condición extrapolítica, donde por imperio del derecho natural no puede haber dominio exclusivo de iure de alguien sobre sus bienes (es decir, donde no hay cosas mías ni tuyas, incluso cuerpo), hay sin embargo acciones y palabras owned, poseídas en derecho y con exclusividad por personas naturales. Si así no fuera, los hombres que se encuentran en condición de naturaleza no tendrían cómo autorizar al futuro soberano, ni cómo comprometerse con cada semejante a asumir las palabras y acciones que aquel emitiera como propias. La condición de autor de cada uno de los signatarios del pacto originario, su derecho de hablar y actuar en nombre propio, es previa, como elemental condición de posibilidad, a la constitución del poder soberano que habilitará para cada uno de ellos el derecho positivo de llegar a ser propietario exclusivo de ciertos bienes y del propio cuerpo. Tendriamos así que, en condición de naturaleza, cada uno es y no es owner, cada uno reconoce y no reconoce en el otro un derecho último sobre algo que le pertenece solo a él. Una manera de encarar esta aporía sería pensar que para Hobbes está implícito que el verbo poseer (to own), y el consiguiente sustantivo poseedor (owner) tienen un significado básico que se especifica según el tipo de objetos a que estos términos se refieren. Una cosa es poseer palabras y acciones; otra, ser dueño de bienes fisicos o externos. Para lo segundo, según la doctrina hobbesiana, hace falta la habilitación positiva y la protección del Estado; para lo primero, basta el orden jurídico de la Naturaleza. Conceptualmente, solo siendo persona natural se puede pronunciar con algún tipo de validez performativa el fiat coral que pone a existir al Estado. Ser autor (artifice último de palabras y acciones, persona natural responsable, etcétera) equivale, dice Hobbes, a tener derecho de autoría. Dado que, por ser teóricamente previo a la constitución de la autoridad soberana, el de autoría no puede ser un derecho civil, la única opción que queda es que sea un derecho natural ${ }^{35}$. En condición de naturaleza, el derecho

\footnotetext{
34 Ibid., I, 16, p. 112.

35 Coincidimos, en este punto, con una lectura que privilegia en la teoría del derecho natural en Hobbes más una expresión del poderío que anima la vida activa de cada hombre que una mera falta de limitaciones externas, como la de Volpato Dutra, D.J., "As leis naturais em Hobbes", en: Revista Latinoamericana de Filosofia, v. XLI, 2 (2015), pp. 171-190, p. 174.
} 
natural de cada uno de mis semejantes los habilita a intentar disponer de mi cuerpo, pero no de mi voluntad. No porque desde una perspectiva moral no deban intentarlo, sino porque metafisicamente no pueden. Mi voluntad, que ejerce la mediación entre la multiplicidad de pasiones e imágenes internas y mi aparición externa, unificada y ordenada por la acción o el dicho, es, como luego por extensión lo será la soberanía política, algo ontológicamente inalienable. Es verdad que aparecer y representarse son formas relacionales del ser que se dan necesariamente ante un otro. Pero mi semejante, que a partir de mi aparecer conjetura y reconoce el carácter específicamente humano de mi vitalidad y productividad interiores, hace esto a modo de comprobación, no de concesión. La voluntad y la capacidad hermenéutica elemental del otro no son la causa de mi condición iusnatural de persona autoral y autorrepresentativa, sino la ocasión para su manifestación.

Reafirmamos lo que decíamos antes. Incluso y especialmente en la condición brutal de enemistad de todos contra todos, lo primero siempre es una decisión hermenéutica moral que consiste en reconocer en el otro un derecho natural de autoria, solo después de la cual se opta por permanecer respecto de mi reconocido como semejante en estado de enemistad, o de intentar superar dicha situación poniendo en marcha el lento y cuidadoso proceso de exteriorización de las actitudes que en el fuero interno manda la ley natural. En Hobbes, la condición de persona natural, al ser una expresión eminente (aunque entrelineada) del derecho natural, es ontológicamente prioritaria respecto de la constitución de personas artificiales en general y de las unidades politicas soberanas en particular. El owner natural es el quien último al que, adjudicándole una cierta responsabilidad por la exteriorización de sus intenciones, dichos y acciones, interpela la ley natural. Si bien Hobbes llama "caos originario" "36 a la condición natural de guerra de todos contra todos, esta no es una situación de absoluta confusión indiscriminada. Por el contrario, lo que hay en la condición extraestatal es una coexistencia de personas naturales, que a la vez que poseedoras universales de cosas y cuerpos son y se conciben reciprocamente como autoras/poseedoras particulares y exclusivas de acciones y palabras.

\section{Personificar e interpretar al representante soberano.}

Hay una dualidad que es intrínseca al concepto de persona artificial. En el caso específico de los monarcas soberanos, Hobbes alude a esta dualidad

${ }^{36}$ Por ejemplo: “...first chaos of violence, and Civill War" (Hobbes, T., Lev., III, 36, p. 300). 
diciendo que estos tienen dos "capacidades" (capacities): una politica, asociada a la representación de la persona de la república; otra natural, que corresponde al hombre investido con tal dignidad. Algo similar ocurre con las asambleas soberanas. Ellas portan, en modo politico, la persona del Commonwealth y portan también la representación de los miembros particulares de la asamblea misma, entendida como caso especial de sistema regular ${ }^{37}$. En este contexto, capacity puede entenderse como la combinación de propósitos, necesidades y recursos que cabe adjudicar a la persona en cuestión. La capacidad pública de quienes ejercen la representación soberana involucra un monto y una clase de poder que es acorde con la finalidad superior con la que se constituye el cuerpo político. Este poder, sabemos, es el más grande que puede asistir a un artificio de factura humana, porque se nutre de los bienes y fuerzas que aportan todos los miembros de la asociación política y porque debe proteger a todos ellos en su integridad física y jurídica. Es absoluto porque, por hipótesis, al representar a la república, no rinde cuentas por sus acciones ante ninguna institución sobre la tierra ${ }^{38}$. Sin embargo, por lo que venimos diciendo, el hecho de que el poder de quien gobierna un Leviatán sea máximo y que su derecho sea absoluto no significa que el ejercicio efectivo de los mismos esté libre de toda determinación o criterio de evaluación. Por el contrario, lo está y en dos sentidos, uno moral y otro estructural.

En el sentido moral, los hombres que ejercen la soberanía deben responder en el fuero interno de su conciencia ante los preceptos de la razón natural, que es la que dictamina los contenidos generales a los que deben intentar servir ${ }^{39}$. Esos contenidos generales son una cierta aplicación del espíritu de las leyes de naturaleza a las funciones del officium. En el Capítulo 30 Hobbes las enumera como un a priori de la estatalidad: provisión al bienestar de la población, instrucción cívica y religiosa, legislación adecuada, preservación de los derechos de soberanía, cargas impositivas igualitarias, un sistema de premios y castigos equilibrado, dirección del poder de policía y milicia, etcétera. Dado que el accionar de los representantes soberanos tiene -por más íntima que esta sea- una instancia de evaluación, es obvio que Hobbes está dando a entender que hay maneras de estar y de no estar a la altura del

\footnotetext{
${ }^{37}$ Ibid., II, 23, p. 166. Para una lectura contextualista, que ve en la distinción de las dos capacidades del soberano una intención de proteger al monarca contra los argumentos rebeldes parlamentaristas, $c f$. van Apeldoorn, L., "On the Person and Office of the Sovereign in Hobbes's Leviathan", en: British Journal for the History of Philosophy, v. I (2019), pp. 1-20.

${ }^{38}$ Hobbes, T., Lev., II, 18, p.124.

${ }^{39}$ Ibid., II, 30, p. 231.
} 
cargo. Nuestro pensador, es verdad, desprecia a los que toman tiranía como un adjetivo negativo, pero lo hace solamente para dejar en claro que es una imposibilidad teórica sostener que al súbdito lo puede asistir un derecho positivo para juzgar y, eventualmente, condenar o destituir a un soberano en ejercicio $^{40}$. La dualidad propia del dispositivo de la personificación artificial de la que venimos hablando, entonces, aparece en forma disvaliosa cuando existe una distancia inapropiada entre la voluntad efectiva del representante y las exigencias de su función, o cuando sucede una intromisión indebida de las necesidades y pasiones de la personalidad natural del gobernante supremo. Lo primero sucede o bien por ignorancia o bien por falta de carácter. A tono con la manera sencilla en que resume la cuestión el propio Hobbes, la función soberana no está bien servida si los gobernantes actúan ignorando los principios que obligan a armar y sostener una arquitectura de poderío racional y absoluto (intentando justificar, por ejemplo, los conquistadores, la causa que los llevó a ocupar el territorio) o si, conociéndola, temen ejercerla en plenitud como si el mango de la espada pública fuera demasiado caliente para empuñarlo con firmeza $^{41}$. Lo segundo ocurre cuando el soberano, aun conociendo las líneas generales de su responsabilidad y disponiendo de los recursos adecuados para intentar llevarlas a cabo, prefiere actuar en contra de los dictados de la recta razón, recurriendo, sin que ello sea operativamente indispensable a excesos de crueldad, a favoritismos irritantes o a imposiciones empobrecedoras y humillantes que atentan contra la dignidad de sus gobernados. Si bien nada de lo que actúe el soberano puede ser injusto strictu sensu, Hobbes se pronuncia con firmeza en contra de estas formas de ejercer el poder y las llama iniquidades ${ }^{42}$.

Hay otro tipo de condicionamiento que modula la comprensión de lo que debemos entender cuando Hobbes dice que el derecho de soberanía es absoluto. Este derecho está servido por un poder que es inmenso, pero instrumental. Esto significa que es independiente, en buena medida, de las cualidades naturales de quienes lo ejercen, porque está conformado por la confluencia de una multiplicidad de voluntades. Podría decirse que el poder del soberano es un poder delegado en él y también por él. El poder delegado en el soberano es el mencionado en la fórmula del compromiso fundante que, en teoría, suscribió cada súbdito y que consiste en una amplia variedad de recursos. El conductor de Leviatán es uno de los poderosos de la tierra porque ejerce un control

\footnotetext{
40 Ibid., IV, 46, p. 470.

41 Ibid., "Revisión y conclusión", p. 486.

42 Ibid., II, 18, p. 124.
} 
sobre la estructura estatal que lo habilita a percibir impuestos y a asignar presupuestos, disponer la distribución y apropiación de los bienes materiales (tierras, edificios, instrumental), decretar levas para la milicia y para instruir a los habitantes según su interpretación de lo que es justo, bueno y piadoso. Para poder manejar efectivamente y no solamente de iure este volumen de poder económico, militar, administrativo e ideológico, el soberano necesita de la concurrencia de sus colaboradores más cercanos, que son quienes, mediante un parcelamiento de las diferentes áreas de la incumbencia política, ponen su voluntad, carácter y prudencia al servicio de las capacidades públicas de su jefe supremo. El poder de la república se hace efectivo a través de una red de ministros, secretarios de hacienda, jueces, generales, rectores de universidades, sacerdotes, diplomáticos, etcétera, y por estos, todavía, es capilarizado a través de los eslabones subalternos de las respectivas cadenas de mando. Ellos, dice Hobbes, como brazos, visión y mente del inmenso hombre artificial, son las "partes orgánicas", es decir, esenciales, de la soberanía ${ }^{43}$. Sentado en el puente de mando de la nave estatal, el soberano depende de la colaboración de su cuerpo de ministros como la voluntad de un hombre depende del vigor y respuesta sana de sus miembros, articulaciones y órganos vitales y perceptivos

Aquí se vuelve a verificar la dualidad esencial que afecta a las personas artificiales pensando, ahora, en los servidores públicos. Dualidad que es legitima y productiva cuando cada agente estatal, en la medida de su nivel jerárquico de responsabilidad, enriquece la intención general de los commands recibidos con su presencia inmediata y con la aplicación bienintencionada de su prudencia específica en tanto militar, economista, diplomático, parlamentario, etcétera. Sin embargo, puede volverse ilegitima si se anteponen los intereses y pasiones personales privados hasta el punto de descuidar, tergiversar o francamente contrariar el espíritu de la tarea delegada. Es verdad que los servidores estatales son súbditos y que, por tanto, están sometidos de facto y de iure al poder ordenador y coercitivo que maneja el soberano. En tal sentido, la capacidad de daño de un funcionario está tan contenida como la de cualquier ciudadano o habitante del país. Pero también es verdad que, si bien parcelado y expuesto a una variedad de controles, ellos comparten la responsabilidad y el ejercicio del poderío estatal. Disponen de un resto de libertad que no puede ser disciplinado con el expediente del temor a la Espada Pública porque son ellos precisamente quienes manejan dicho instrumento en tiempo real. Esta es la razón por la que

${ }^{43}$ Ibid., II, 23, p. 166. 
Hobbes recela de los militares exitosos, de los sacerdotes o de los profesores universitarios ${ }^{44}$.

El caso de los jueces, dada la centralidad de su función en la arquitectónica de la república, es muy ilustrativo para nuestro interés. Empecemos por recordar que Hobbes explica que una ley es la manifestación de una voluntad que está investida con el derecho para obligar o impedir determinado tipo de acciones a un conjunto de personas que, previamente, se habían comprometido con dicha autoridad. En el caso de una república que, como vimos, no tiene una única voz natural, la expresión de la voluntad legislativa corresponde al representante soberano. A él corresponde también, como parte de su oficio, disponer de los recursos necesarios para propiciar la observancia de sus leyes mediante la previsión de un sistema de incentivos, con premios y castigos físicos, económicos o simbólicos. En cuanto a lo formal, la ley, para ser válida, debe ser suficientemente conocida y acreditada como emitida, o consentida en caso de que sea una disposición muy antigua, por la autoridad soberana. Es en cuanto a lo sustantivo que surgen algunas complejidades. En primer lugar, está la cuestión de la intervención hermenéutica de los jueces. Toda ley debe ser interpretada. Es parte de su naturaleza que lo que ella indica esté apenas mencionado por la letra que la expresa, y que su auténtico significado deba conjeturarse atendiendo a la supuesta intención de su autor. La interpretación de cada ley en cada caso concreto, dice Hobbes, es "la circunstancia material que la vuelve obligatoria” ${ }^{45}$. El soberano, que es su emisor legítimo, no puede estar efectivamente presente en la sustanciación de cada procedimiento judicial y tampoco puede indicar por escrito la interpretación de cada norma que promulga, porque de este modo la cadena de interpretaciones requeridas implicaría un retorno al infinito. En segundo lugar, está la diferencia, tampoco prescindible, que puede existir entre los intereses y opiniones privadas de la persona natural que se desempeña como magistrado judicial, de un lado, y las responsabilidades del cargo, del otro. Nuestro punto es que esta segunda diferencia, que al superar un cierto margen tolerable puede tergiversar y corromper toda la lógica del edificio estatal, tampoco puede ser cuidada por una reglamentación positiva. Puede suceder, y no es grave, señala Hobbes, que, de buena fe y con plena inteligencia, un juez encuentre y consigne, al intervenir en un caso concreto, una contradicción entre dos leyes civiles que concurren al entendimiento de la cosa a ser juzgada. Puesto al corriente de tal situación,

44 Ibid., II, 29, p. 229.

45 Ibid., II, 26, p. 190. 
que no fue prevista por el legislador, el soberano, que posee el monopolio de la Razón Pública, elimina la contradicción sin mayores conflictos, ya sea mediante intervención como fallo de última instancia, ya sea mediante modificación de alguna de las dos leyes. Lo que no debe ocurrir, señala el filósofo, es que un juez, motu proprio, se desentienda del deber de tratar de figurarse la verdadera razón que pudo haber motivado al soberano a promulgar una ley determinada y que no ajuste su sentencia (que es un decir performativo) a dicho espíritu. Su fallo, en ese caso, en lugar de ser la sentencia del soberano, es decir, en lugar de actualizar la presencia de la voluntad del soberano "sería la (sentencia) suya propia, y, por tanto, injusta..." ${ }^{46}$.

Ante la circunstancia de que una instrucción soberana no esté escrita, como es el caso de las interpretaciones de las leyes civiles, el criterio general es que la circunstancia material que la complete debe ser provista por la propia razón del funcionario, y esta no debe ser entendida como la que calcula, en modo necio, sus intereses exclusivamente privados. Este criterio, que ilustramos con el caso de un juez, vale también, por extensión, para la actitud de interpretación leal para con las órdenes recibidas que debe observar servidor público: Todas estas instrucciones (no escritas) de la Razón Natural pueden ser comprendidas bajo el nombre de Fidelidad, que es una rama de la justicia natural"47.

Igual que sucedia en el pacto fundante de autorización, nos encontramos con la necesariedad de una actitud propiamente moral. Una usticia natural que, asociada a la ontología de la representación, aparece como a priori ya no del comienzo de la existencia del artificio estatal, sino de su conservación y correcto funcionamiento. El juez que personifica a su soberano al entender en un litigio y que, ejerciendo la virtud de la fidelidad, emite una sentencia "justa" -es decir, acorde con la letra y el espíritu de la ley civil que está aplicando-, contribuye de dos maneras a evitar el retorno de la condición natural de guerra. En primer lugar, porque contiene, mediante un uso mínimo del poder de coerción, el progreso de una situación conflictiva entre particulares que, librada a su propia dinámica, podría llegar a tornarse peligrosamente violenta. En segundo lugar, porque aporta a la firmeza de la estructura estatal misma al consolidar la relación de confianza recíproca que debe existir entre el alma de la soberanía y sus manifestaciones, por así decir, localizadas, externas y materiales. La plenificación concreta de la Razón Pública requiere, como condición necesaria, que cada juez -y, por extensión, cada servidor público investido de poder y

46 Lev., II, 26, p. 187. Énfasis agregado, nuestro paréntesis.

47 Ibid., p. 188, paréntesis de Hobbes. 
autoridad-, en su fuero interno, reemplace por la fidelidad las "virtudes" de la fuerza y el fraude, que son propias de la condición natural de guerra, y que, con su accionar virtuoso, subordine las inclinaciones de su conciencia privada, que para Hobbes es mera opinión ${ }^{48}$, en favor de la presencia, figurada pero efectivamente pacificadora, de la voluntad soberana. La Fidelity, esa "rama de la justicia natural", asociada conceptualmente a las personificaciones del soberano en el ejercicio de la función pública, es condición moral imprescindible para hacer de la inevitable multiplicidad fáctica de poderes y agentes estatales una real unidad de voluntad y propósito.

\section{Las dos personas del ciudadano}

Todo proceso de representación en general confluye sobre la persona ante la cual el último eslabón de la cadena de autorizaciones viene a descargar su responsabilidad. En el caso del ciudadano, esta matriz general adopta una peculiaridad muy significativa. La doctrina de Hobbes establece que la serie genérica A-B-C ha de ser concebida, para el caso de la relación entre la autoridad politica y los súbditos, como A-B-Á. La misma persona natural que en la asamblea fundante intercambió con todos sus coterráneos una promesa de autorización en favor del futuro representante soberano es la que, ahora como súbdito, debe considerarse protegida y obligada por la voluntad de ese poder irresistible que había contribuido a generar cuando pronunció o consintió aquel contrato ficticio. Se trata de una construcción ideal, compleja y exigente. No es esperable, dada la antropología propuesta por Hobbes, que todos los ciudadanos la conozcan, ni que estén dispuestos a tenerla siempre presente como guía de su accionar ${ }^{49}$.

Ilustremos nuestro punto imaginando un caso relativamente sencillo, propio de una situación cotidiana de la vida en una república. Un oficial de la agencia de ingresos públicos se presenta ante un propietario y lo notifica de una deuda importante con el fisco, por impuestos impagos desde larga data. Reclamada y sometida la controversia a juicio de los magistrados, la última instancia de apelación confirma el monto reclamado y los punitorios a saldar

\footnotetext{
48 Ibid., I, 7, p. 48.

49 Señala Lucien Jaume, acertadamente a nuestro entender, que, por más forzada que pueda aparecer esta reversión de la representación sobre el representado, no es más que la lógica que vivifica el acontecimiento teatral, donde el espectador asiste a la representación de escenas con las que debe sentirse identificado, y, básicamente, la que da cuenta de la economía de la Redención en el cristianismo (Jaume, L., "Théorie de la personne fictive dans le Leviathan de Hobbes", en: Revue Francaise de Science Politique, v. VI (1986), pp. 1009-1035).
} 
y dispone penas alternativas de confiscación o prisión para la eventualidad de incumplimiento. Si este es su caso, es probable que la conducta y los pensamientos del hombre modelizado por Hobbes en la primera parte del Leviatán hayan discurrido por alguna de las siguientes trayectorias. En su momento, no tomó debida cuenta de los impuestos, públicamente anunciados, que debió haber tributado, o tal vez especuló con que la burocracia estatal no sería tan eficaz como para detectar su incumplimiento. Es posible que hasta haya tratado de sobornar a algún oficial de cuentas de su distrito. En todo caso, llegado el momento de enfrentarse con la opción de pagar o ir a la cárcel, protestó, en la intimidad de su hogar, acerca de la ambición desmedida y cruel de los agentes del Tesoro. Se quejó de la manera sesgada y exagerada en la que dictaminaron los juece. Lamentó, en fin, la injusta suerte del que vive sometido a un poder irresistible que oprime y castiga sin ofrecer contraprestaciones que justifiquen la obediencia $^{50}$. Termina nuestro hombre hobbesiano promedio, saldando su deuda de alguna manera, por mero temor al castigo. No obstante, cabe advertir que, si la intensidad de su resentimiento llega a ser comparable con la angustia que le genera la imagen de la represalia, será un posible cuadro presto a ser captado por liderazgos rebeldes ${ }^{51}$. Su estado de ánimo lo inclina peligrosamente hacia la condición espiritual del necio, que ha dicho en su corazón que no existen ni la justicia ni Dios y que, por tanto, considera que puede ser racional y conveniente para él que, en determinadas ocasiones, prefiera incumplir el pago de una obligación contraída. Con todo lo probable que sea este estereotipo, no es él, obviamente, la sal de la tierra leviatánica.

Ahora bien, existe otra posibilidad, llamémosla, "godolphiana",52 . Nuestro ciudadano ejemplar puede haber traspapelado algún recibo o puede haber

\footnotetext{
50 "Pues todos los hombres estás provistos por naturalezade de lentes multiplicadoras (sus pasiones y amor de sí), a través de las cuales, todo pequeño pago aparece como una pesada carga; pero están desprovistos de esas lentes prospectivas (la ciencia moral y civil), que permite ver desde lejos las miserias que los acechan, y que no pueden ser evitadas sin tales pagos" (Hobbes, T., Lev., II, 18, p. 129; paréntesis de Hobbes).

${ }^{51}$ La lectura de Martinich, en cierta forma, convalida el sentimiento de ajenidad de nuestro ciudadano promedio. Para este autor, Hobbes violenta el concepto de representación cuando lo presenta como una delegación irrevocable a alguien que, en lugar de subordinarse a su mandante, pasará a tener sobre él un derecho absoluto de gobierno (Martinich, A., Hobbes Dictionary, Nueva York: Blackwell, 1985, pp. 38-39). Para una lectura en contrario, que rescata la actitud filosóficamente soberana con la que Hobbes hace una apropiación semántica de los términos relevantes para su doctrina, $c f$. Condren, C., "Natura naturans: Natural Law and the Sovereign in the Writings of Thomas Hobbes", en: Hunter, I. y D. Saunders (eds.), Natural Law and Civil Sovereignty, Londres: Palgrave Macmillan, 2002, pp. 61-75.

52 Hobbes, T., Lev, "Revisión y conclusión", pp. 483-484, en donde Hobbes presenta a Mr Sidney Godolphin como modelo de caballerosidad virtuosa y a la vez dispuesta por naturaleza a cumplir
} 
delegado sus asuntos en un administrador poco atento. Notificado de su deuda con el fisco, presenta su caso ante las autoridades respectivas y defiende su posición con un sano autointerés, pero el resultado, lamentablemente, es el mismo que para su conciudadano ya mencionado. Debe pagar la deuda con más intereses y costos. La teoría hobbesiana nos sugiere que este segundo ciudadano, al estar en presencia del oficial de hacienda o luego ante los jueces, "vea" en ellos, guardando afinidad con el sueño de Sócrates en el Critón, toda una serie de personificaciones, acreditaciones, intereses y voluntades que, partiendo de los cuerpos, palabras y papeles escritos y sellados que tiene delante y ascendiendo retrospectivamente por todos los eslabones de la cadena de mando, llegue, en su conjetura, hasta la mismísima boca, mente y corazón de su monarca, o de los miembros de la asamblea soberana. Incluso que, sin detenerse allí, continúe pasando por la persona de la república hasta llegar a la escena originaria de la asamblea, en la que él mismo, hastiado de la miseria de su condición natural, decidió, libre y voluntariamente, desprenderse irrevocablemente de su derecho de autogobierno poniendo a disposición de quienes dirigen el Estado sus fuerzas y sus bienes.

La exigencia para con la imaginación del ciudadano observante es mayor aun si consideramos que el mismo Hobbes admite que la institución de la república se celebra con carácter irrevocable una sola vez que las generaciones sucesivas deben ir asumiendo cada vez como propio el compromiso celebrado por sus antecesores y que, además, la historia no registra prácticamente ninguna república que no haya comenzado por alguna forma de imposición forzada. $\mathrm{El}$ ciudadano observante no solo debe relatar y convalidar en su mente una serie de personificaciones, comisionadas y asumidas por voluntades supuestamente justas, de las que no tiene ninguna constancia sensorial (a saber: las que van desde la voluntad del monarca hasta su ejecución efectiva, por parte de los oficiales), sino que también debe representarse otro conjunto de escenas que muy probablemente nunca sucedieron ni pudieron haberlo tenido a él como protagonista (las del proceso ideal de constitución del poder soberano mismo). En cierto modo, el contribuyente justo de Hobbes es como el judío observante,

en plenitud con sus deberes de obediencia y lealtad para con el soberano. Para un estudio contextual de la posible influencia de la relación personal entre Hobbes y la familia Godolphin sobre la obra politica del filósofo, $c f$. Martel, J., Subverting the Leviathan, Nueva York: Columbia University Press, 2007; para una lectura en clave utilitaria, que descree de la honorabilidad como motor relevante para el cumplimiento de las obligaciones civiles en la doctrina hobbesiana, $c f$. Cortés, F., "La ética de la autoconservación y la teoría de los deberes políticos en el Leviatán de Hobbes", en: Areté, v. XIV, 1 (2002), pp. 5-40. 
que todos los años, al celebrar el Pesaj, enseña a sus hijos, tal como le indicara Moisés en la Torá, que ellos mismos (y no solamente sus antepasados) han sido esclavos en Egipto, liberados por el brazo firme de Yahvé, rebeldes adoradores del becerro de oro, caminantes del desierto, conquistadores de Canaán, etcétera $^{53}$. La ejecución de la voluntad del representante soberano, que en el nivel macroscópico realiza la unidad de la multitud reduciendo la multiplicidad de voces a una única voz, también tiene la virtud salvífica de poner a cada ciudadano en paz consigo mismo porque, al obligarlo a asumir sus compromisos impositivos y sus deberes civiles en general, lo hace retornar al único camino correcto que puede hacer lícito y real su derecho civil de propiedad y seguridad.

La percepción de la legitimidad soberana en el nivel micro no es sencilla. Es verdad que el poder de la espada pública es indispensable para desalentar a los díscolos, para castigar a los transgresores y para dar merecida tranquilidad a los ciudadanos respetuosos de la ley. El problema es que la fuerza, por sí sola, es insuficiente. Del mismo modo en que sin acuerdo de consentimiento no basta la victoria sobre un ejército enemigo para que el generalísimo triunfante pueda considerarse soberano por adquisición de la población que ha quedado desprotegida $^{54}$, tampoco puede el puro terror obligar a que los súbditos se dispongan a cumplir con sus compromisos cívicos. También está el problema de que ningún Estado tiene la capacidad policial suficiente como para forzar a cada uno de los miembros de la población, si estos le han retirado su adhesión intima, a cumplir con las disposiciones legales. En cuanto a su efectividad fáctica, los Estados, en este aspecto, son como los bancos que, simplemente y por razones puramente conceptuales, no tienen cómo responder ante la demanda urgida de devolución de todos los depósitos cuando se produce una corrida. La fuerza de la espada estatal es un poder instrumental y parte de su matter es la confianza que, en términos de ciudadanía, también debe ser entendida como fidelity. La observancia generalizada de las normas y disposiciones soberanas, que mantendría los niveles de delincuencia y disidencia interna en un nivel tolerablemente manejable, requiere, según el propio Hobbes, de la voluntad consciente del súbdito que, al igual que el juez o que el ministro, tiene la responsabilidad de prestar su razón para aplicar a su caso personal el entendimiento de cada ley ("to which individuall persons may apply their own

53 Deut. 4: 9-10.

54 Hobbes, T., Lev, “Revisión y conclusión”, p. 485. 
cases") ${ }^{55}$. Esta es la misma lógica del precepto que solventa la existencia de un ejército nacional, obligando a defender en tiempos de guerra al soberano que garantiza la vida confortable en tiempos de paz y que, hacia el final del libro, es presentado por Hobbes como una anexa ley natural, es decir, como un principio a priori de la estatalidad ${ }^{56}$.

La cuestión replica con sus peculiaridades lo que señalábamos en el apartado anterior respecto de los jueces en particular y de los funcionarios en general. La condición para la persistencia normal de la relación de protección y obediencia entre el Estado y los súbditos no es pasible de ser forzada por las penas asociadas al incumplimiento de las leyes civiles porque se trata, otra vez, de un compromiso moral de cada persona natural, asociado, conceptualmente, con una percepción competente de la figura de la representación. La contundencia fáctica de los poderes de judicatura, policía y defensa, imprescindible y patente como la presenta el imaginario hobbesiano, es ella misma tributaria de un complejo conceptual que establece la prioridad ontológica de la interioridad voluntaria y consciente por sobre la conducta exterior meramente utilitaria.

\section{Apoyo teológico al principio de personalidad.}

El Capítulo 31 de Leviatán es el último de la Parte Segunda y se intitula "Del reino de Dios por naturaleza". En su primer párrafo, Hobbes dice que habiendo demostrado casi todo lo concerniente a los fundamentos de los derechos de los soberanos y las libertades y obligaciones de los súbditos, solo faltaría explicar cómo se pueden compatibilizar los deberes de obediencia al soberano civil, que gobierna un cierto territorio, y a Dios, que reina sobre todo el Universo. Este último paso resulta indispensable para alcanzar un "conocimiento entero" del problema de la legitimidad de la relación entre súbditos y gobernantes, ya que su adecuada elucidación permitirá encontrar un equilibrio que evite caer en el extremo de ofender a la Divina Majestad por "demasiada obediencia civil", o en el extremo opuesto de transgredir las disposiciones de la república por temor a la voluntad de $\operatorname{Dios}^{57}$. Esta remisión de lo político a un marco teológico recorre en verdad todo el libro que es, tal como reza el subtítulo,

\footnotetext{
55 Ibid., II, 30, p. 231. Para un estudio que discute la visión de un Hobbes antecedente del totalitarismo del siglo XX, en tanto pone el juicio individual prudente como correlato de una soberanía vigorosa, cf. Branstetter, J., "The Leviathan's Conscience: Hobbesian Human Nature and Moral Judgement”, en: Political Research Quarterly, v. IV (2019), pp. 778-789.

56 Ibid., "Revisión y conclusión", p. 484.

57 Ibid., II, 31, p. 245.
} 
un tratado sobre la república "eclesiástica y civil". Dado que las referencias a la doble condición de artífice y gobernante de la voluntad divina pueden ser legítimamente elaboradas por la sola razón filosófica, sin ayuda de la revelación sobrenatural, que es asunto de la Parte III del Leviatán, conviene que tomemos breve nota de algunos condicionantes y analogias que refuerzan a nuestro entender la relevancia del concepto de person como articulador teórico de todas las formas de interacción entre voluntades dotadas de poder e inteligencia.

En tanto causa suprema de todo cuanto conforma el Universo, el Dios que postula Hobbes tiene un poder irresistible. Esta condición se traduce al ámbito práctico como un sometimiento de todos los hombres, lo quieran o no, a Su voluntad. Dios, siendo omnipotente, no está amenazado por peligro alguno y por tanto no tiene necesidad de ceder su derecho natural de libre disposición sobre todo hombre y toda cosa. En este punto Hobbes establece dos precisiones. En primer lugar, advierte que gobernar, en sentido propio y no meramente metafórico, implica dar a conocer con signos suficientes una voluntad con derecho de mando a un conjunto de personas que reconozcan dicha autoridad, y que tengan la posibilidad -digamos, ontológica- de acatarla o desobedecerla. Los seres inanimados y los irracionales no son súbditos en sentido propio del reino natural de Dios porque no pueden pecar. Tampoco basta la relativa autonomía de una libertad inteligente para poder integrar dicho reino. Para que un hombre sea súbdito de Dios por Naturaleza es necesario un estado íntimo de reconocimiento y aceptación: debe creer en su existencia y providencia y debe tener disposición a la obediencia de sus leyes, para aspirar a la recompensa que dicho cumplimiento conlleva y para evitar el consiguiente castigo en caso de transgresión. Quienes no comparten este estado existencial de creencia y disposición, dice Hobbes, son enemigos ${ }^{58}$.

Comencemos por destacar lo que Hobbes mismo explicita en diversas ocasiones y es que concebir a Dios como gobernante en su reino natural implica atribuirle una cierta personalidad. Esta atribución, como sucedía en el caso de las relaciones interpersonales entre mortales, es un ejercicio hermenéuticopráctico que actualiza cada súbdito cuando, a partir de indicios sensibles, como los fenómenos naturales, o inteligibles, como los preceptos de razón, conjetura la acción sostenida y la legislación promulgada por una voluntad única. Claro que esta suposición de existencia invisible y poderosa es común a monoteístas e idólatras y está propiciada por una cierta religiosidad natural, que es una

58 Ibid., p. 246. 
inclinación antropológica común a toda la especie humana ${ }^{59}$. Por eso dice Hobbes que pueden ser representados tanto los ídolos como los dioses de la antigüedad pagana y, desde luego, el mismo Dios de la tradición monoteísta ${ }^{60}$. La diferencia entre ambas formas de creencia, la adecuada y la supersticiosa, no es solo cuestión de fe, sino también está solventada por un talante racional de búsqueda encadenada de causas que termina por concluir, si bien en la forma de hipótesis, en una única fuente última emisora de todo ser y orden ${ }^{61}$. Hay una brecha insalvable entre la infinitud de la persona divina y la limitada capacidad cognitiva de los hombres, por eso corresponde observar una prudencia reverente al momento de postular afirmaciones de indole teológica. Atribuir voluntad a Dios no debe confundirse con suponer en Él deseos y apetitos, que solo se dan en quien tiene una naturaleza carente. Hobbes lo resume con una paráfrasis del pasaje de Éxodo, en el que Jehová se revela a Moisés mediante una zarza ardiente $^{62}:$ "...solo hay un nombre que puede expresar nuestra concepción de Su naturaleza: YO SOY”63.

La condición de personalidad soberana del Dios de la teología racional de Hobbes es un aporte significativo a la consistencia de su concepción política. Además del mencionado origen divino de las leyes de naturaleza, principio fundante de toda estatalidad que es comunicado a los hombres por vía de la recta razón, está la célebre analogía con la que se inicia la Introducción de Leviatán. Así como Dios es creador de seres vivos en general y de la humanidad en particular, los hombres son capaces de imitar la productividad del artífice divino, a la que Hobbes llama Naturaleza, creando máquinas en general, que son una especie de vida artificial automática, y Estados en particular, cuya alma es la soberanía. Lo humano y lo politico son, respectivamente, las obras más excelentes de cada creador porque están dotadas de vida y racionalidad y

\footnotetext{
59 Ibid., I, 12, pp. 75-76. Sobre el apoyo teórico que aporta la remisión de lo político en Hobbes a un marco teológico, cf. Willms, B., "One Head, One Word, One Crozier. The Signification of Theology in Hobbes's Leviathan", en: Borrelli, G. (ed.), Le ragione del moderno tra teologia $e$ politica, Nápoles: Morano, 1990, pp. 65-77; también Pacchi, A., "Hobbes and the Problem of God", en: Rogers, G. y A. Ryan (eds.), Perspectives on Thomas Hobbes, Oxford: Oxford University Press, 1990, pp. 171-188; y Martinich, A., The Two Gods of Leviathan, Cambridge: Cambridge University Press, 1992. Para una perspectiva en contrario, de talante straussiano, que ve el Capítulo 31 como una construcción defensiva que intenta mantener a raya la ingerencia que, por vía de la tradición, ejercía la teología en la filosofia puramente inmanente de lo político, cf., Stauffer, D., Hobbes's Kingdom of Light. A Study of the Foundations of Modern Political Philosophy, Chicago: The University of Chicago Press, 2018.

${ }^{60}$ Ibid., I, 16, p. 113-114.

${ }^{61}$ Ibid., I, 11, p. 74.

62 Ex. 3:14.

63 Hobbes, T., Lev., II, 31, p. 251.
} 
porque son generadas mediante una dicción performativa: los fiat del Génesis y del contrato originario ${ }^{64}$. La cualidad ordenadora y benéfica de la providencia divina aparece ratificada, por ejemplo, en el Capitulo 36, en donde se afirma que, si en un sentido metafórico se puede decir que la sabiduría, el poder y la disposición eterna con que se armoniza el universo son como "palabras" que expresan la voluntad de Dios ${ }^{65}$, en un sentido literal debe admitirse lisa y llanamente que "no existe inclinación hacia lo bueno que no sea una (secreta) operación de Él”" . La imitación de dicha productividad benéfica y providente está presente en la imagen del Capítulo 17, que muestra a la república como un Dios Mortal que, entre todos los dispositivos de factura humana, opera como fuente máxima de la seguridad y el confort que pueden esperar los hombres en su existencia terrenal. La comparación planteada por Hobbes, a todas luces, busca asociar la salus populi que debe intentar ofrecer la dirección del Estado a una ciudadanía observante de sus disposiciones con la esperanza de salvación eterna que habilita la fe obediente de los creyentes en Dios y en su Cristo.

Por último, quisiéramos destacar que la analogía entre los dones benéficos de la divinidad y de la estalidad se refuerza con el hecho, ya aludido más arriba, de que ambos soberanos, el universal y el terrenal, se representan. A los fines de especificar los términos y alcances de su voluntad, que se expresa mayormente en forma de leyes generales, y también para ratificar con signos visibles la existencia de una personalidad que, de tan tremenda y poderosa, no conviene que aparezca de manera inmediata en el trajín codidiano de la vida normal, ambos soberanos delegan emanaciones de su autoridad en personas artificiales que ejercen como mediadores. Los gobernantes humanos lo hacen a través de sus ministros y oficiales; Dios, a través de sus profetas y de su propio Hijo. Esta analogía que, en cierto sentido, es formal, se potencia con el hecho significativo de que el soberano representa ante sus súbditos a la persona de Dios ya que solo el monarca, o la asamblea soberana, tienen Su autorización inmediata para educar e instruir al pueblo ${ }^{67}$. En los Estados modernos, el soberano ocupa, como lo hiciera Moisés, el sitial de lugarteniente de la persona divina y funge como intérprete decisivo de su voluntad a todos los fines legales y religiosos $^{68}$. De esta manera, vemos que la carga de representación que debe

\footnotetext{
${ }^{64}$ Hobbes, T., Lev., Introd., pp. 9-10.

65 Ibid., III, 36, p. 288.

66 Ibid., p. 296.

67 "Solo el Monarca, o la Asamblea Soberana, tienen Autoridad inmediata por parte de Dios (Immediate Authority from God), para educar e instruir al pueblo..." (ibid., II, 23, p. 167).

68 Ibid., III, 40, p. 324.
} 
figurarse ante una instancia estatal el súbdito de una república bien ordenada es sofisticadamente doble ya que, si de un lado debe retroceder en una serie de personificaciones hasta una versión imaginada de sí mismo en desolada condición de naturaleza, del otro debe ascender hasta la voluntad misma del Señor del universo. El súbdito leal de una república civil debe considerarse a sí mismo a la vez como autor y como creatura del poder personificado que lo obliga y protege ${ }^{69}$.

\section{Conclusiones}

La maestría retórica y argumentativa de Hobbes genera efectos inquietantes en sus lectores. Por momentos, la contundencia conceptual con la que el filósofo se aplica a deconstruir la concepción de una continuidad fluida entre la naturaleza humana y la politicidad que postulaba la metafisica clásica ha sido tan exitosa que, al poner en primerísimo plano las múltiples expresiones de la condición "dinámica y peligrosa" de los grupos humanos (según recupera el célebre dictum de Carl Schmitt), parece inhibir la posibilidad de una superación institucional por vias racional-instrumentales. Son tantas y tan complejas las competencias de interpretación y las actitudes de autolimitación que la construcción hobbesiana requiere de sus integrantes, que se diría que, evaluado en los términos de su propia antropología, el modelo propuesto resulta demasiado exigente. La solución que viene a ofrecer Leviatán frente a los embates recurrentes de Behemoth luce más lejana a medida que se revela como más urgente.

Lo anterior vale igualmente para la concepción del momento excepcional que inaugura el artificio político y, en una escala más reducida y menos dramática, para las situaciones cotidianas de su funcionamiento normal. Consideremos brevemente la narración legitimante del pasaje de la condición natural a la condición civil. Si el contrato que genera al Estado es afectivamente indispensable, porque la coexistencia sin una poderosa autoridad común se ha tornado miserable y brutal, entonces su realización es prácticamente imposible. En una situación tal, nadie con un mínimo grado de introspección y con conciencia responsable de lo que mandan las leyes de naturaleza en cuanto al

\footnotetext{
${ }^{69}$ Coincidimos aquí con el señalamiento de Crignon, que ve en el concepto hobbesiano de representación como un término polisémico, que cumple la función de aunar la mediación entre el campo inmanente y la trascendencia, Recuperando para la modernidad jurídico-instrumental la riqueza de la identidad propiciada por la lógica de la encarnación (cf. Crignon, P., De l'incarnation a la représentation. L'onthologie politique de Thomas Hobbes, 2012, p. 469).
} 
deber de autopreservación debería estar dispuesta a confiar en las capacities personales y políticas de nadie. Los efectos antisociales de esta prevención prudencial desactivan toda intención de renunciar a las actualizaciones del derecho natural, tanto en la celebración de los compromisos horizontales con los futuros conciudadanos, como en la autorización vertical ascendente de las futuras autoridades. Razones análogas deberian perturbar el ánimo de quien, como opción por el menor de los males, se ha visto obligada a convalidar el señorio de un conquistador. Dado que no hay base legal para limitar el ejercicio del poder del representante soberano y que hay que consentir en que este permanezca en condición de naturaleza respecto de sus súbditos, ¿no sería ingenuo confiar en que el gobernante, motu proprio, se esforzará de buena fe en extremar los puntos de coincidencia entre sus pasiones y gustos personales, de un lado, y los intereses de la población gobernada, del otro? ¿Por qué habría que esperar que abandone el hábito de cultivar las virtudes cardinales de la fuerza y el fraude quien, por hipótesis, no ha cedido nada de su derecho natural y que, por tal razón, se encuentra en una situación similar a la de un dios? ${ }^{70}$.

Hobbes no ignora estas objeciones que se originan, como ya hemos sugerido, en el núcleo mismo de lo que su teoría necesita establecer como dato fundante para una doctrina politica que no peque de idealista. Ofrece, en consecuencia, dos tipos de respuestas. Algunas son puntuales y, a nuestro entender, un tanto escuetas. Dice Hobbes, por ejemplo, que a todo gobernante le conviene que el país que dirige sea fuerte y próspero porque de ello depende su bienestar personal, así como la propia seguridad frente al ataque de potencias enemigas. En la misma linea de razonamiento, también afirma el texto que el bienestar de la población es un propósito utilitariamente indispensable del oficio soberano porque el descontento popular puede ser fácilmente atizado por liderazgos inescrupulosos y ambiciosos y la persona privada del gobernante se encuentra severamente amenazada en la eventualidad de una rebelión ${ }^{71}$. En otras palabras, que el autointerés bien entendido es un regulador natural de las relaciones políticas de poder, una vez que estas ya están constituidas y asentadas por la costumbre.

\footnotetext{
${ }^{70}$ Para una postura crítica acerca de las distorsiones en punto a legitimidad que introduce la hipótesis de la república por adquisición en el Leviatán, cf., Tarlton, Ch., "To Avoyd the Present Stroke of Death: Despotical Dominion, Force, and Legitimacy in Hobbes's Leviathan", en: Philosophy, v. LXXIV (1999), pp. 221-245.

71 Hobbes, T., Lev., II, 30, p. 240.
} 
Más allá de una lectura en clave meramente utilitaria, queremos reparar en lo que podría ser una defensa de tipo sistémica, habilitada, y hasta exigida por una lectura integral del propósito doctrinario de nuestro filósofo. La contraobjeción hobbesiana, en esencia, diría que, si lo que se plantea es la duda de que una república de necios como los que describe el Capitulo 15 pueda llegar a existir y persitir, la respuesta obvia es que no. Ninguna multitud de personas que haya dicho en sus corazones que la opción por prácticas recurrentemente injustas es una vía racional y admisible para perseguir el propio bienestar será capaz de abandonar la condición de naturaleza o de impedir su retorno ante la menor circunstancia que sus miembros puedan llegar a considerar como adversa en la intimidad de sus conciencias ${ }^{72}$. Es necesario disponerse seriamente a obedecer a las autoridades consentidas y a respetar la propiedad e integridad de los conciudadanos, si es que se aspira a vivir protegido y en paz. Por razones simétricas también es necesario proteger a los súbditos y querer, en el fuero interno, propiciar su bienestar, si es que se aspira a ser obedecido con lealtad.

El espíritu de esta idea generalísima es moderno e iluminista. Encontramos su enunciación explícita en los primeros párrafos del Capítulo 29. Esquemáticamente, el argumento es el siguiente: los hombres disponemos de una racionalidad que usualmente no ejercemos en la plenitud de sus posibilidades. Si lo hiciéramos, propone Hobbes, podriamos comenzar a habitar un espacio político común en el que no estuviésemos molestándonos unos a otros. La república sería una especie de edificio colectivo que podría albergar confortablemente a varias generaciones sucesivas y que no se derrumbaría una y otra vez sobre nuestras cabezas por defectos estructurales de su arquitectura ${ }^{73}$. La condición indispensable para que este proyecto pueda realizarse y conser-

\footnotetext{
72 Ibid., II, 15, p.101. Patricia Springborg, en linea con Skinner, considera que el tratamiento del foole que hace Hobbes es acorde con su postura epicúrea y agnóstica, por lo que recurre a imágenes bíblicas como la del necio a los fines meramente instrumentales y retóricos, no argumentativamente sustantivos (Springborg, P., "Hobbes's Foole the 'Insipiens' and the Tyrant-King", en: Political Theory, v. XXXIX, 1 (2011), pp. 85-111). Para una discusión acerca cuál sea la clase de necedad que contraria la lógica del contrato social, si la proclamada o la silente pero experimentada con convicción, cf. Hoekstra, K., "Hobbes and the Fool", en: Political Theory, v. XXV (1997), pp. 620-654 y Hayes, P., "Hobbes's Silent Fool: A Response to Hoekstra", en: Political Theory, v. XXVII, 2, (1999), pp. 225-229. Para una lectura del necio de Hobbes como figura compatible con el talante contractualista, pero fatalmenete antipolítica por mor de su ateísmo, $c f$. Dotti, J., "El Hobbes de Schmitt", en: Cuadernos de Filosofia, v. XXXII (1988), pp. 57-68.

73 Ibid., II, 29, p. 221. Coincidimos en este punto con una lectura que asocia el carácter artificial del Estado hobbesiano con la conciencia responsable y a la vez autointeresada acerca de sus principios fundantes por parte de sus ciudadanos y funcionarios: Fernández Peychoux, D., "El Leviatán como autómata: método y política en Thomas Hobbes", en: Anales del Seminario de historia de la filosofia, v. XXX, 2 (2013), pp. 413- 430.
} 
varse, afirma el filósofo, consiste en observar los principios de razón que exigen que el poder soberano sea absoluto. Ante la posible objeción de que tales principios no sean más que una fantasía sin asidero, dado que nunca ha habido en la historia una república duradera que asignara derechos absolutos a la soberanía, el autor responde que argumentar así constituiría una falacia. Sería equivalente a que un nativo americano afirmara que son ilusorios los principios que permiten construir edificios sólidos, cómodos y que se conserven estables por muchos siglos solo porque en su existencia poco tecnologizada él no ha conocido más que endebles chozas de barro. Los avances del estudio sobre cada sector de la naturaleza pueden propiciar mejoras para las condiciones de vida que hasta hacía poco eran inimaginables. Así como ha progresado la ciencia de los materiales, de los suelos y de las figuras, para beneficio de la arquitectura, así también ha avanzado, si bien todavía solo en su aspecto teórico y por mérito exclusivo del propio Hobbes, el conocimiento de los fundamentos de la politica ${ }^{74}$.

Este símil con el arte constructivo da a entender que la doctrina que describe la naturaleza de ese inmenso hombre artificial que es el Leviatán no se limita a proponer una visión ideal de lo que debería ser el Estado, sino que también indica cuáles son los principios que mínimamente deben ser respetados para hacer posible la mera existencia de un orden politico. Así como en arquitectura hay leyes fundamentales que deben ser observadas, aunque de modo intuitivo y no consciente, para conseguir que una simple choza logre permanecer erguida más de unas pocas horas, así también hay en las sociedades políticas normas elementales -obediencia, protección, unidad del poder soberano, monopolio de la facultad legislativa, etcétera - que se cumplen de hecho y en cierta forma a espaldas de la conciencia de sus integrantes. Conocerlas, aplicarlas y enseñarlas haría que los gobernantes del tiempo presente estuvieran en condiciones de empezar a construir edificios civiles abrigados y cómodos, más acordes con el estado de avance de la ciencia moderna. No es necesario, entonces, para ir a la objeción antes mencionada, que el pacto inaugural democrático y unánime haya sucedido realmente. Todas las repúblicas conocidas de la historia han comenzado por conquista e imposición violenta, pero, si las que de alguna u otra manera se han mantenido unidas son beneficiadas con la combinación de prudencia y pedagogía que recomienda Hobbes, es razonable pensar que estas podrian alcanzar una situación de su cultura institucional en la que la mayor parte de los miembros de las futuras generaciones asumirán

${ }^{74}$ Ibid., II, 30, p. 232. 
sus compromisos de lealtad y obediencia con plena responsabilidad, como si hubiesen sido signatarios voluntarios de un contrato instituyente.

Digamos, para cerrar estas notas, que la fundamentación de la doctrina del Estado en Leviatán requiere formular una combinación adecuada de las diferentes flexiones del ideologema Nature. Es muy significativa la manera en la que Hobbes pone este término en primer plano en lugares de presentación y de resumen del texto. Se trata de encontrar cuál es la verdadera naturaleza del Estado, que ha sido diseñado en imitación de ese arte divino que es la Naturaleza (Introducción), de remitir dicho constructo a sus dos pilares básicos que son "las conocidas inclinaciones naturales de los hombres" y las leyes de naturaleza ("Revisión y conclusión"), además de inscribir el conjunto en el marco jurídico generado por la voluntad divina cuando esta impera de modo natural (Capítulo 31, último de la Parte Segunda). Que esta tarea filosófica esté bien resuelta, como Hobbes considera, significa que se ha concebido un entramado jurídico con atribución de poderes, derechos y responsabilidades a gobernantes, agentes estatales y ciudadanos tal que, si el representante soberano y sus servidores desempeñan sus cargos según una interpretación sensata de las leyes de naturaleza, los súbditos se encontrarán inmersos en un horizonte de estimulos y frenos que inducirá sus opiniones y acciones a nutrir la prosperidad ordenada del conjunto de la república. Esto, a su vez, es confluyente con la necesidad de vivir de acuerdo con los mandatos de Dios.

La dinámica de la personificación es, como hemos intentado mostrar, una de las cualidades basales de la naturaleza humana y su elaboración conceptual constituye un aporte esencial para la tarea de fundamentación. El ejercicio del derecho natural de autoría, potenciado por una cadena de autorizaciones y de correlativas competencias perceptivas, es una experiencia cotidiana en la vida social. El hombre común, tal como se ilustró en el Capítulo 16, ejerce y decodifica personificaciones, naturales y artificiales en diferentes situaciones de su vida civil y privada, tanto prosaica como religiosa. La representación, para seguir con el simil arquitectónico, explica tanto la microfisica de la articulación de cada uno de los elementos que constituyen el edificio cuanto las lineas generales de fuerza que hacen a la estabilidad del conjunto. En este sentido, la figura de la personificación se beneficia por analogía del clásico argumento del contextualismo de clave marxista de un Macpherson, que veía las relaciones contractuales como una práctica constitutiva del individualismo 
posesivo en la incipiente socialidad capitalista ${ }^{75}$. Sin embargo, a los fines de su función fundamentadora, la teoría hobbesiana de la persona corre con una ventaja adicional sobre la forma mentis contractualista porque, como hemos visto, hunde sus raíces en el aspecto más problemático de la condición de naturaleza, y alli provoca la contradicción (diriamos dialéctica) que la estatalidad debe intentar superar. En la condición de enemistad universal se da la paradoja de que, de un lado, cada uno se sabe dueño legítimo de sus acciones y dichos, que son la libre exteriorización de parte de su vida afectiva y cognitiva interior, y reconoce lo propio en cada otro; pero, del otro, y en pleno y legitimo ejercicio de su derecho natural, tiene la potestad de negar a todos sus semejantes el derecho de dominio exclusivo sobre algunas cosas y aun sobre sus propios cuerpos. La vida en la condición natural es brutal y miserable, entre otras razones, porque alli se da el contraste doloroso de que la dignidad de la dimensión espiritual de los hombres, indispensable para la animosidad belicosa, resulta negada cuando esta pretende realizarse en la objetividad del propio cuerpo y de los bienes externos que hacen a su conservación y confort. El Estado, al sancionar el derecho de propiedad, resuelve esa contradicción y garantiza a cada ciudadano la posesión legítima de su cuerpo y de sus bienes a cambio del tributo de obediencia y de la eventual rendición de cuentas por sus dichos y acciones. Enmarcando lo anterior en un horizonte cosmo-teológico, se puede decir que la noción de person permite referir, por causación y analogía, el orden político inmanente a una instancia de trascendencia, lo cual confiere al modelo de Hobbes un elemento adicional de consistencia.

Todo esto es lo que el Foole-como contrafigura antipolítica- no ve. No ve a Dios como fuente última de todo principio de legislación racional y eterna. No ve las analogías legitimantes implicadas en la figura conceptual de la representación política porque es ciego a la Fidelity, que es una rama de la justicia natural. El necio no es súbdito, en sentido propio, ni del reino de Dios por naturaleza, ni del reino de los hombres por artificio. No puede, por tanto, autopercibirse como coautor ficcional del "hagamos al Estado" originario y, desde luego, tampoco puede imaginarse siquiera la posibilidad de que alguien como el soberano, que dispone de un enorme poderío fáctico, sea capaz de volver reflexivamente sobre sí mismo autolimitando los impulsos pasionales de su capacidad natural con las exigencias de la legalidad natural, que son también las responsabilidades de su cargo. En ambos reinos, el necio es súbdito solo de manera impropia.

\footnotetext{
${ }^{75}$ Macpherson, C., La teoría politica del individualismo posesivo. De Hobbes a Locke, Madrid: Trotta, 2005.
} 
Como las piedras, que son forzadas a caer según su gravedad, él apenas puede ser forzado a obedecer porque en la espada del oficial de seguridad solo ve eso: la amenaza de una espada blandida por una persona natural. Debido a que el necio confia excesivamente en su capacidad para engañar siempre a todos, Hobbes advierte que con esa posición existencial se arriesga a comunicar, con su desprecio por la racionalidad práctica de la justicia, un mensaje que lo volvería inaceptable como miembro de cualquier tipo de asociación. No solo por su nula disposición a honrar las deudas contraídas, sino porque, en un nivel metafísico, el necio solo sabe de cosas y de cuerpos. Al no renunciar in foro interno a su derecho natural, es ontológicamente incompetente para percibir en los demás esa relación de confianza recíproca que supone el dispositivo de la personificación. Por tanto, es inepto para moverse de manera adecuada en el mundo civil de las propiedades y las autoridades autorizadas, donde (casi) todos los demás lo han hecho.

Los hombres que Hobbes sugiere que conozcamos por vía de introspección no somos, mayoritariamente, ni necios, ni caballeros. Aunque sea ilusorio esperar que muchos ciudadanos alcanzarán el grado de excelencia moral de un virtuoso como Godolphin, la naturaleza de las repúblicas indica que, para persistir en su existencia y abrigar la esperanza de una mejora sustantiva en sus niveles de armonía y prosperidad interior, sus gobernantes deben poder reducir a un mínimo el número de necios encubiertos que las habitan. El concepto de persona, concluimos, es fundamento de la doctrina estatal que desarrolla Hobbes en su Leviatán porque, en tanto elemento esencial de la naturaleza del hombre, participa conceptualmente de la vitalización de las articulaciones de la vida civil, así como de la generación de su existencia misma. Asimismo, al permitir la remisión de todo el dispositivo de autoridad a la suprema voluntad creadora del mundo, conjeturable por vía natural, consolida la legitimidad de la construcción política ante la mirada del hombre racional que, porque no es necio, asume la propia finitud.

Recibido: $15 / 03 / 2020$

Aceptado: 06/08/2020 


\section{Bibliografia}

Branstetter, J., “The Leviathan's Conscience: Hobbesian Human Nature and Moral Judgement”, en: Political Research Quarterly, 4 (2019), pp. 778-789. https://doi. org/10.1177/1065912917717817

Brito Vieira, M., The Elements of Representation in Hobbes, Leiden/Boston: Brill, 2009. https://doi.org/10.1163/ej.9789004181748.i-286

Brito Vieira, M., "Revisiting Hobbes on Representation", en: Hobbes Studies, v. XXXI (2018), pp. 25-29. https://doi.org/10.1163/18750257-03101004

Crignon, P., De l'incarnation a la représentation. L'onthologie politique de Thomas Hobbes, París: Garnier, 2012.

Condren, C., "Natura naturans: Natural Law and the Sovereign in the Writings of Thomas Hobbes", en: Hunter, I. y D. Saunders (eds.), Natural Law and Civil Sovereignty, Londres: Palgrave Macmillan, 2002, pp. 61-75. https://doi. org/10.1057/9781403919533_5

Cortés, F., "La ética de la autoconservación y la teoría de los deberes políticos en el Leviatán de Hobbes", en: Areté, v. XIV, 1 (2002), pp. 5-40.

Dotti, J., "El Hobbes de Schmitt", en: Cuadernos de Filosofia, v. XXXII (1988), 57-68.

Dotti, J., "La representación teológico-política en Carl Schmitt", en: Avatares Filosóficos, v. I (2014), pp. 27-54.

Dumouchel, P., "Persona: Reason and Representation in Hobbes's Political Philosopphy", en: Substance, v. XXV, 2 (1996), pp. 68-80. https://doi.org/10.2307/3685330

Fernández Peychoux, D., "El Leviatán como autómata: método y política en Thomas Hobbes”, en: Anales del Seminario de historia de la filosofia, v. XXX, 2 (2013), pp. 413-430. https://doi.org/10.5209/rev_ASHF.2013.v30.n2.44054

Foucault, M., Microfisica del poder, Madrid: Las Ediciones de la Piqueta, 1979.

Green, M., "Authorization and Political Authority in Hobbes", en: Journal of the History of Philosophy, v. LIII, 1 (2015), pp. 25-47. https://doi.org/ 10.1353/hph.2015.0005

Hayes, P., "Hobbes's Silent Fool: A Response to Hoekstra", en: Political Theory, v. XXVII, 2 (1999), pp. 225-229. https://doi.org/10.1177/0090591799027002004

Hermosa Andújar, A., "Sociedad natural y Estado en Hobbes", en: Fragmentos de Filosofia, v. VII (2009), pp. 49-85.

Hobbes, T., Leviathan, Nueva York: Cambridge University Press, 1991.

Hoekstra, K., "Hobbes and the Fool", en: Political Theory, v. XXV (1997), pp. 620-654. https://doi.org/10.1177/0090591797025005002

Jaume, L., "Théorie de la personne fictive dans le Leviathan de Hobbes", en: Revue Francaise de Science Politique, v. VI (1986), pp. 1009-1035. https://doi. org/10.3406/rfsp.1983.394103

Macpherson, C., La teoría politica del individualismo posesivo. De Hobbes a Locke, Madrid: Trotta, 2005.

Lessay, F., "Hobbes Covenant Theology and its Political Implications", en: Springborg, P. (ed.), The Cambridge Companion to Hobbes's Leviathan, Cambridge: Cambridge University Press, 2007, pp. 243-270. https://doi.org/10.1017/ CCOL0521836670.011 
Martinich, A., Hobbes Dictionary, Nueva York: Blackwell, 1985.

Martinich, A., The Two Gods of Leviathan, Cambridge: Cambridge University Press, 1992. https://doi.org/10.1017/CBO9780511624810

Martel, J., Subverting the Leviathan, Nueva York: Columbia University Press, 2007. https: / / doi.org/10.7312/mart13984

Pacchi, A., "Hobbes and the Problem of God", en: Rogers, G. y A. Ryan (eds.), Perspectives on Thomas Hobbes, Oxford: Oxford University Press, 1990, pp. 171-188.

Pitkin, H., "Hobbes's Concept of Representation", en: American Political Science Review, v. LVIII, 2 (1964), pp. 328-340. https://doi.org/10.2307/1952865

Ricoeur, P., Hermenéutica y acción, Buenos Aires: Prometeo libros, 2008.

Rilla, R., El Leviatán como prosopopeya: hacia una nueva teoría del conflicto en Hobbes, Buenos Aires: TeseoPress, 2019.

Runciman, D., "What Kind of Person is Hobbes's State? A Reply to Skinner", en: Journal of Political Philosophy, v. VIII (2000), pp. 268-278. https://doi. org/10.1111/1467-9760.00102

Sagar, P., "What is the Leviathan?", en: Hobbes Studies, v. XXXI (2018), pp. 75-92. https://doi.org/10.1163/18750257-03101005

Skinner, Q., "Hobbes and the Purely Artificial Person of the State", en: Journal of Political Philosophy, v. VII (1999), pp. 1-29. https://doi.org/10.1111/1467-9760.00063

Skinner, Q., "Hobbes in Persons, Authors, and Representation", en: Springborg, P., (ed.), The Cambridge Companion to Leviathan, Nueva York: Cambridge University Press, 2007, pp. 157-180. https://doi.org/10.1017/CCOL0521836670.007

Springborg, P., "Hobbes's Foole the 'Insipiens' and the Tyrant-King”, en: Political Theory, v. XXXIX, 1 (2011), pp. 85-111. https://doi.org/10.1177/0090591710386700

Stauffer, D., Hobbes's Kingdom of Light. A Study of the Foundations of Modern Political Philosophy, Chicago: The University of Chicago Press, 2018. https://doi. org/10.7208/chicago/9780226553061.001.0001

Tarlton, Ch., "To Avoyd the Present Stroke of Death: Despotical Dominion, Force, and Legitimacy in Hobbes's Leviathan", en: Philosophy, v. LXXIV (1999), pp. 221-245. https://doi.org/10.1017/S0031819199000273

van Apeldoorn, L., "On the Person and Office of the Sovereign in Hobbes's Leviathan", en: British Journal for the History of Philosophy, v. I (2019), pp.1-20. https:/ / doi. org/10.1080/09608788.2019.1613632

Volpato Dutra, D. J., "As leis naturais em Hobbes", en: Revista Latinoamericana de Filosofia, v. XLI, 2 (2015), pp. 171-190.

Willms, B., "One Head, One Word, One Crozier. The Signification of Theology in Hobbes's Leviathan”, en: Borrelli, G. (ed.), Le ragione del moderno tra teologia e politica, Napoli: Morano, 1990, pp. 65-77.

Zarka, Ch., "Personne civile et répresentation politique chez Hobbes", en: Archives de Philosophie, v. XLVIII (1985), pp. 87-31. 